\title{
MPRA
}

Munich Personal RePEc Archive

\section{A Global Lending Channel Unplugged? Does U.S. Monetary Policy Affect Cross-border and Affiliate Lending by Global U.S. Banks?}

Temesvary, Judit and Ongena, Steven and Owen, Ann L.

1 August 2015

Online at https://mpra.ub.uni-muenchen.de/65913/

MPRA Paper No. 65913, posted 05 Aug 2015 04:32 UTC 
A Global Lending Channel Unplugged?

Does U.S. Monetary Policy Affect Cross-border and Affiliate Lending by Global U.S. Banks?

\author{
Judit Temesvary * \\ Hamilton College and Cornell University \\ 490 Uris Hall, Cornell University, Ithaca, NY 14853 USA \\ 1-607-592-5875. jt275@cornell.edu \\ Steven Ongena \\ University of Zurich, Swiss Finance Institute and CEPR \\ Plattenstrasse 32 (PLD F-02), CH-8032 Zurich, Switzerland \\ 41-44-634-39-54. steven.ongena@bf.uzh.ch
}

\author{
Ann L. Owen \\ Hamilton College
}

198 College Hill Road, Clinton, NY 13323, USA

1-315-859-4419. aowen@hamilton.edu

August 2015

* Corresponding author. We would like to thank seminar participants at Lancaster University and the Universities of Kent and Essex, and colleagues at the Departments of Economics at Cornell University and Hamilton College for helpful comments. 


\section{A Global Lending Channel Unplugged?}

\section{Does U.S. Monetary Policy Affect Cross-border and Affiliate Lending by Global U.S. Banks?}

Abstract: We examine how U.S. monetary policy affects the international activities of U.S. Banks. We access a rarely studied US bank-level dataset to assess at a quarterly frequency how changes in the U.S. Federal funds rate (before the crisis) and quantitative easing (after the onset of the crisis) affects changes in cross-border claims by U.S. banks across countries, maturities and sectors, and also affects changes in claims by their foreign affiliates. We find robust evidence consistent with the existence of a potent global bank lending channel. In response to changes in U.S. monetary conditions, U.S. banks strongly adjust their cross-border claims in both the pre and post-crisis period. However, we also find that U.S. bank affiliate claims respond mainly to host country monetary conditions. (123 words)

Keywords: bank lending channel; monetary transmission; global banking; cross-country analysis

JEL classification: E44; E52; F42; G15; G21 


\section{Introduction}

In today's globally interconnected financial system, the effects of a central bank's actions reach far beyond national borders. Monetary policy, in particular, can affect local and international financial markets in numerous ways: via interest rates, asset prices, and the availability of credit. These monetary effects can then feed into the real side of the economy.

While the impact of monetary policy on the supply of credit in the domestic economy has been widely analyzed (Bernanke and Blinder (1992), Kashyap and Stein (2000), Jiménez, Ongena, Peydró and Saurina (2012)), recent attention has turned to the impact of monetary policy on the supply of credit to borrowers located abroad. The rise of global banks, i.e., banks which lend to borrowers cross-border or maintain foreign affiliates in many other countries, over the past two decades has added a sense of urgency to the study of potential "global" bank lending channels. ${ }^{1}$ Following monetary easing at home, global banks can both increase cross-border flows to other countries via the external capital market and send funds to their foreign affiliates via the internal capital market.

Recent empirical work (à la Peek and Rosengren (1997)) has shown that globally active U.S. banks have relied on both these channels in response to domestic financial (Cetorelli and Goldberg (2011), Cetorelli and Goldberg (2012)) and monetary policy shocks (Cetorelli and Goldberg (2012)). The utilization of both the external and internal capital markets implies that U.S. banks actively reallocate claims between the U.S. and other countries. As such, the global banks' reliance on these channels not only reduces the domestic impact of the bank lending channel of monetary policy, but also spreads U.S. monetary policy

${ }^{1}$ Cross-border spillovers of domestic monetary policy actions are receiving increasing policy attention in recent years. The Vice Chairman of the Federal Reserve System Stanley Fischer for example recently noted that: "In a progressively integrating world economy and financial system, a central bank cannot ignore developments beyond its country's borders, and the Fed is no exception. This is true even though the Fed's statutory objectives are defined as specific goals for the U.S. economy .... And of course, actions taken by the Federal Reserve influence economic conditions abroad. Because these international effects in turn spill back on the evolution of the U.S. economy, we cannot make sensible monetary policy choices without taking them into account" (Fischer (2014)). Our paper addresses this recent policy concern by quantifying some of the global spillover effects of U.S. monetary policy actions. 
effects abroad. In light of the well-established benefits of developed-country banks' lending in emerging markets (Goldberg (2007)), the expansion of U.S. bank claims abroad in times of U.S. monetary easing can have beneficial effects on recipient economies.

While the reallocation of funds following changes in domestic monetary conditions has been documented within global banks and between countries, ${ }^{2}{ }^{3}$ in this paper we examine the transmission of U.S. domestic monetary policy across other countries, ${ }^{4}$ through changes in cross-border and affiliate bank exposures. Using an individual bank-level regulatory dataset that covers the globally most active U.S. financial institutions' domestic and foreign activities between 2003 and 2013, we study how changes in the stance of U.S. monetary policy (as measured by changes in the Federal funds rate in the pre-crisis, and in quantitative easing in the post-crisis period) affects U.S. banks' bilateral cross-border and foreign affiliate flows. We define cross-border flows as changes in direct claims by the bank's headquarters located in the home country on the foreign country, while affiliate (local) flows are changes in claims acquired by the subsidiaries or representatives of U.S. banks located in foreign countries.

\footnotetext{
${ }^{2}$ Closest related to our paper in this respect is Cetorelli and Goldberg (2012), who use U.S. bank-level data to examine the impact of U.S. monetary policy on global U.S. banks' foreign lending. As opposed to our analysis that studies the external capital markets in detail, they focus on the specifics of banks' internal capital markets. Accordingly, they look at how U.S. monetary policy affects flows between the U.S. parent bank and foreign offices via internal capital markets, and how these internal flows impact total foreign lending by U.S. banks' affiliates abroad. Focusing on external capital markets, our study differs by looking at bilateral bank flows of various types at the bank-host country level, controlling for not only U.S. but host country macro and monetary conditions as well.

${ }^{3}$ Cerutti, Claessens and Ratnovski (2014) for example use country-to-country level data on cross-border bank flows to study the non-price determinants of the cross-border supply of credit. They find that global liquidity is driven primarily by uncertainty (VIX), US monetary policy (term premia but not federal funds rate per se), and UK and Euro Area bank conditions (proxied by leverage and TED spreads). Dinger and te Kaat (2015) study the impact of countrylevel current account balances on individual bank risk-taking. See also He and McCauley (2013), Lo Duca, Nicoletti and Vidal Martinez (2014), Cerutti, Hale and Minoiu (2015) and McCauley, McGuire and Sushko (2015).

${ }^{4}$ Focusing on individual "recipient" countries, Ioannidou, Ongena and Peydró (2014) for example assess if changes in the US federal funds rate have compositional effects on the supply of US Dollar denominated credit granted in Bolivia (an almost entirely dollarized country), Coleman, Correa, Feler and Goldrosen (2014) study the flows of nonU.S. affiliate private banks in Brazil, Morais, Peydró and Ruiz (2015) assess the impact of foreign monetary policies on lending by foreign versus domestic banks in Mexico, and Ongena, Schindele and Vonnák (2015) study the differential impact of domestic and foreign monetary policy on the local supply of bank credit in domestic and foreign currencies in Hungary. However these papers do not assess - as we do - the impact of a domestic monetary policy on the supply of cross-border and affiliate credit abroad by many individual banks across many different countries.
} 
As in Kashyap and Stein (2000), our identification strategy is based on the hypothesis that - due to the resultant differential funding constraints - less liquid or capitalized global banks exhibit a stronger response to changes in monetary conditions at home than their more liquid or better capitalized counterparts.

We find strong evidence that U.S. monetary easing (tightening), as measured by changes in the Federal funds rate, is associated with meaningful increases (decreases) in the bilateral cross-border flows of U.S. banks in the pre-crisis period. This effect is substantially stronger for both less-liquid and for lesscapitalized banks. We also find some evidence that unconventional monetary policy (quantitative easing) in the post-crisis period, as measured by increases in the Fed's purchases of Treasury securities, significantly increases bilateral cross-border flows by U.S. banks. These results are also present when studying maturity or target sector-specific credit flows. Finally, we show that the increases and decreases in these cross-border flows in response to changes in U.S. monetary policy are largest in the lower income countries. Our results also suggest that while U.S. banks' foreign affiliate flows are significantly affected by the bank lending channel of host country monetary policy in the pre-crisis period, the stance of U.S. monetary policy has no significant impact on these affiliate flows. In some auxiliary estimations we find that U.S monetary easing also contributes to U.S. banks' decision to enter new host markets in the pre-crisis period.

Our main contributions to this literature are as follows. First, our results show the significant impact of U.S. monetary policy on U.S. banks' cross-border flows via external capital markets, i.e., to non-affiliated parties abroad. These results complement previous results on the existence of the bank lending channel in U.S. banks' internal capital markets abroad (Cetorelli and Goldberg (2012)) and U.S. banks' foreign affiliate lending abroad (Morais, Peydró and Ruiz (2015), Cetorelli and Goldberg (2012)). 
Second, our bilateral financial flows data at the bank-host country-maturity and bank-host countrysector level allows us to directly control for changes in conditions that are likely to affect the demand for investment by U.S. banks abroad. Since our goal is to identify U.S. monetary policy effects on the supply of bank credit to foreign countries, our use of a broad set of fixed effects to control for demand-side changes allows for a clearer identification of the bank lending channel (Bernanke and Gertler (1995)).

Third, our data extends to the first quarter of 2013, providing us with a substantially longer time horizon to examine the impact of U.S. quantitative easing on the international bank lending channel than previous work. Comparing the pre- vs. post-crisis periods using a difference-in-difference approach, Cetorelli and Goldberg (2012) for example document a more severe lending contraction over time by liquidity-constrained banks. Morais, Peydró and Ruiz (2015) show the expansionary effect of U.S. quantitative easing on the lending of U.S. banks through foreign affiliates. We study the impact of quantitative easing on cross-border flows while carefully controlling for changes in time-varying demandside conditions throughout and in the aftermath of the financial crisis. We find some evidence of a postcrisis bank lending channel, i.e., that quantitative easing (measured by decreases in the U.S. shadow short-term rate and the Fed's sale of U.S. Treasury securities) increases the bilateral cross-border flows of funding-constrained U.S. banks significantly more than their unconstrained counterparts after the onset of the crisis.

The remainder of the paper proceeds as follows. Section 2 describes the empirical methodology in detail, and presents the model specifications. Section 3 describes the data, and Section 4 presents the results of the estimation. Section 5 examines the period after the onset of the financial crisis when the Federal Reserve heavily relied on non-traditional monetary instruments. Section 6 offers some concluding thoughts. 


\section{Empirical Methodology}

Our main specification describes U.S. banks' quarterly cross-border flows as follows. Let $Y_{j, t}^{i, n}$ denote bank $j$ 's holdings of cross-border claims in host country i's at time $t$. The superscript $n$ denotes either target sector (private non-financial, public or financial) or maturity of the claim, depending on the breakdown of the data for a specific estimation. Then $\Delta \ln (Y)_{j, t}^{i, n}$ captures the quarterly change (from time $t-1$ to time $t$ ) of the natural logarithm of the cross-border bank flow of maturity or sector $n$ of bank $j$ into host country $i$. Our specification is as follows:

(1) $\Delta \ln (Y)_{j, t}^{i, n}=\alpha+\sum_{k=1}^{4} \beta_{k} M P_{t-k}^{u s}+\sum_{k=1}^{4} \gamma_{k} M P_{t-k}^{u s} \times C_{j, t-k}+\sum_{k=1}^{4} \delta_{k} C_{j, t-k}+\zeta\left(\begin{array}{c}\text { Bank } \\ \text { Controls }\end{array}\right)_{j, t-1}+$ $\eta\left(\begin{array}{l}\text { Demand } \\ \text { Controls }\end{array}\right)_{t-1}^{i, n}+\varepsilon_{j, t}^{i, n}$

In Equation (1), $\Delta \ln (Y)_{j, t}^{i, n}$ denotes the quarter-to-quarter cross-border flow at the bank-country level as described above. The monetary policy variable $M P$ is the quarterly change in the Federal ("Fed") funds rate from time $t-1$ to $t$. Furthermore, $C$ denotes the bank's liquidity ratio defined as the deposit to assets ratio, later replaced by the capital to assets ratio. As in Kashyap and Stein (2000) and Cetorelli and Goldberg (2012), we focus on the cumulative impact of monetary policy changes over the four preceding quarters. $^{5}$ Therefore, four lags of the monetary shock measure, the liquidity measure, and their interactions are included. ${ }^{6}$ For the maturity-specific specifications, $n$ characterizes remaining maturity: Short-term (less than 1 year) or long term (over 1 year). For the target sector-specific specifications, $n$ characterizes: Financial sector, non-financial private sector or public sector. Bank Controls contains a

\footnotetext{
${ }^{5}$ The inclusion of four lags of the quarterly interest rate changes ensures that we capture the cumulative effect of monetary policy shocks throughout the previous year. While the use of four lags has become standard in the literature, we also repeat the analysis using three and five lags of the monetary policy shocks, and find that our results are robust to changes in the number of lags used.

${ }^{6}$ Since a bank can choose its liquidity ratio strategically, the inclusion of lags of the liquidity ratio that are in time similar to those of the monetary policy shocks (in their levels and interactions) ensures that the liquidity ratio is not endogenous to the interest rate changes.
} 
vector of supply-side variables: Lagged values of bank total assets, capital-asset ratio, return on equity and the ratio of interest plus non-interest expenses to total assets. Lastly, Demand Controls contains various combinations of bank, host country, time and sector or maturity fixed effects to control for changes in demand-side conditions. In addition, Demand Controls contains a Selection Correction term to control for the sample selection bias due to the fact that the dependent variable $\Delta \ln (Y)$ is observed for only a select group of globally active U.S. banks.

We also examine financial flows of foreign affiliates, i.e., these also can be considered "local" bank flows because the affiliate has a local presence in the foreign country. Let $X_{j, t}^{i}$ denote bank j's holdings of local claims in host country $i$ at time $t$. Then $\Delta \ln (X)_{j, t}^{i}$ captures the quarterly (from time $t-1$ to time $t$ ) bank flows of bank j's foreign affiliate in host country $i$. Equation (2) describes our empirical specification.

(2) $\Delta \ln (X)_{j, t}^{i}=\iota+\sum_{k=1}^{4}\left(\theta_{k} M P_{t-k}^{u s}+\psi_{k} M P_{t-k}^{i}\right)+\sum_{k=1}^{4}\left(\kappa_{k} M P_{t-k}^{u s}+\varphi_{k} M P_{t-k}^{i}\right) \times C_{j, t-k}$

$$
+\sum_{k=1}^{4} \chi_{k} C_{j, t-k}+\psi\left(\begin{array}{c}
\text { Bank } \\
\text { Controls }
\end{array}\right)_{j, t-1}+\omega\left(\begin{array}{c}
\text { Demand } \\
\text { Controls }
\end{array}\right)_{t-1}^{i}+\mu_{j, t}^{i}
$$

In addition to the variables described for Equation (1) above, Equation (2) also contains the host country $i$ monetary policy measure $M P_{t}^{i}$ and its interaction with the liquidity ratio $C_{j, t-k} \cdot{ }^{7}$ This monetary measure is defined as the quarterly change in the host country $i$ short-term base interest rate (the local equivalent of the Fed funds rate). The vector Demand Controls contains various combinations of bank, host country and time fixed effects, as well as host country macro controls in some specifications. ${ }^{8}$ Demand Controls also contains a Selection Correction term to control for the sample selection bias due to the fact that the

\footnotetext{
${ }^{7}$ The inclusion of four lags of both the U.S. and host country monetary policy shocks ensures that the cumulative effects of the monetary policy shocks of both countries are captured, even if the timing of the transmission of the U.S. and host country monetary policy effects may differ to some extent.

${ }^{8}$ The inclusion of bank fixed effects also controls for time-invariant bank traits (such as a bank's ownership structure or business model) that may impact global lending flows. The inclusion of time fixed effects controls for cyclicality and seasonality.
} 
dependent variable $\Delta \ln (X)$ is observed for only those U.S. banks who actively maintain an affiliate in host country $i$.

In both Equations (1) and (2), we expect that the direct effect of the U.S. monetary policy shock on bank flows is negative: $\sum_{k=1}^{4} \beta_{k}<0$ and $\sum_{k=1}^{4} \theta_{k}<0$. Our strategy for identifying an international bank lending channel of U.S. monetary policy focuses on the sign of the cumulative coefficients on the interaction term of the bank's liquidity ratio and the U.S. monetary policy shock: $\sum_{k=1}^{4} \gamma_{k}$ and $\sum_{k=1}^{4} \kappa_{k}$. If more liquidity-constrained U.S. banks change their global financial flows more in response to a U.S. monetary policy shock than their liquidity-abundant peers, we expect to find $\sum_{k=1}^{4} \gamma_{k}>0$ and $\sum_{k=1}^{4} \kappa_{k}>0$. If U.S. banks' local (affiliate) flows in foreign countries exhibit a host country lending channel, we would expect to find $\sum_{k=1}^{4} \psi_{k}<0$ and $\sum_{k=1}^{4} \varphi_{k}>0$. Lastly, based on the findings of Temesvary (2014), we expect that all else equal, liquidity-constrained banks maintain higher foreign flows: $\sum_{k=1}^{4} \delta_{k}<0$ and $\sum_{k=1}^{4} \chi_{k}<0$.

\section{Data}

\section{3.a. Data on U.S. banks' foreign claims}

Our main dependent variables are the bilateral cross-border and foreign affiliate bank flows described above. These variables are derived from quarterly bank-level data on U.S. banks' cross-border and foreign affiliate claims from the Federal Financial Institutions Examination Council (FFIEC)'s 009a Data Report form. A U.S. financial institution is required to report foreign country-specific claims on this form (the volumes broken down into cross-border and foreign affiliate claims) if exposure to that given country exceeds one percent of the institution's total assets, or 20 percent of its capital. This dataset contains an unbalanced panel of 82 FFIEC-reporting banks' foreign claims in 75 host markets with 
quarterly frequency over the 2003-2013 period. $^{9}$ Cross-border claims and foreign affiliate claims are reported separately for each host country-bank-time (i.e., year:quarter) combination. ${ }^{10}$ For each bilateral bank-host country pair, cross-border claims are reported in two ways: By remaining maturity (short-term with maturity less than one year and long-term with maturity over one year) and by target sector of investment (financial sector, non-financial private sector and public sector).

Foreign claims are reported on an ultimate risk basis, i.e., after mandated adjustments for transfer of risk exposure. ${ }^{11}$ U.S. banks' cross-border claims are reported on a gross basis, but foreign affiliate (local) claims are reported net of affiliate liabilities. Therefore, the bank level dataset does not allow for the separate analysis of liabilities, and the foreign affiliate claim equations are estimated using net foreign affiliate claims as the dependent variable. In addition, as mentioned above the FFIEC 009a reports data on claims as opposed to loans. As a result, the reported volumes also include assets other than loans such as bonds, stocks, guarantees, etc.; derivate products are excluded from the cross-border claims data however.

While a breakdown by asset type is not available on a bilateral basis, we can use Call Reports data aggregated across all U.S. global banks to examine the composition of claims over time. In 2004, total loans and leases made up 36 percent of U.S. banks' foreign claims (28 percent to private sector, 2 percent to banks, remainder to governments); this share was 35 percent in 2008 (sectoral composition

\footnotetext{
${ }^{9}$ On its website, the FFIEC makes 009a data available starting with the 2003 Q1 quarter.

${ }^{10}$ Data for cross-border claims are taken as Column 4 in the FFIEC 009a forms, and defined as: 'Amount of Crossborder Claims Outstanding After Mandated Adjustments for Transfer of Exposure (excluding derivative products' (column 1) plus 'Amount of Cross-border Claims Outstanding from Derivative Products after Mandated Adjustments for Transfer of Exposure' (Column 3). The sectoral breakdown of cross-border claims is reported in Columns 5 through 7, and maturity-specific claims are shown in Columns 8 and 9). Foreign affiliate claims are defined as 'Amount of Net Foreign Office Claims on Local Residents (including derivative products)' (Column 2).

${ }^{11}$ The risk transfer adjustment implies that the reported amount may differ from the actual (direct, or immediate counterparty) amount extended to the host country. The ultimate risk claims reflect the amount of claims for the repayment of which the given host country is responsible. For instance, if Country A issues guarantees for the loans that the U.S. banks made to Country B, then Country A's ultimate risk exposure would exceed the actual direct investment in that country. Similarly, Country B's reported ultimate risk claims would be less than the actual claims the bank acquired there.
} 
as before), dropped to 27 percent in 2010 and rose back up to 31 percent in 2012 (20 percent to private sector, 7 percent to banks, rest to governments). Deposits with foreign banks made up 13 percent in 2004, remained at this level through 2008, and rose to 15 percent in 2010 and to 18 percent by 2012 . The share of repurchase agreements rose from 7 percent in 2004 to 13 percent 2008, and stayed at that level through 2012. The rest of foreign claims is made up of net due from foreign offices, Treasury and asset-backed securities and guarantees.

Of the reporting U.S. financial institutions, 59 percent are commercial banks, 28 percent are offices of bank holding companies, 7 percent are trade financing offices, and the remaining reporting institutions are in the business of investment banking and securities dealing or sales financing. ${ }^{12}$ There is some regional variation in the allocation of U.S. bank affiliates around the world. While the average European country hosts affiliates of 11 to 12 U.S. banks, South American countries see between 5 and 7 U.S. bank affiliates on average. The average number of U.S. bank affiliates in Asian countries is 5, while this number is substantially smaller in the Middle-East ( 2 U.S. banks). Overall, however, the vast majority of host countries are middle and high income countries, with only a few developing countries in our estimation sample.

Bilateral cross-border and foreign affiliate claims have become increasingly important over time. While on average cross-border claims made up around 7 percent of U.S. banks' total assets in 2003, this number rose to a mean of 12 percent by 2013 . Claims held through local representation, on the other hand, rose from an average portfolio share of 4 percent in 2003 to 17 percent by 2013 . At the bilateral bank-host country level, affiliate claims have become more prevalent relative to cross-border claims. At the country level, the ratio of affiliate to cross-border claims rose from 28 percent in 2003 to 39 percent

\footnotetext{
12 The sample captures an active period of U.S. bank mergers. In order to avoid the problem of big 'jumps' in balance sheets due to mergers, the issue is handled as follows. First, merger events are identified based on the FFIEC's National Information Center's Institution History feature. Starting with the time of merger, the merging banks are then eliminated from the sample. The merged banks are then considered as a newly created entity, which is assigned the original acquiring bank's balance sheet/claims data from then on.
} 
in 2013. Looking at cross-border claims by target sector, 45 percent of such claims are invested in the financial sector, 37 percent in the non-financial private sector and 8 percent in the public sector.

In terms of the diversification of global U.S. banks across foreign countries, any one host country sees a median of 11 percent of a U.S. bank's cross-border portfolio. The number of foreign countries a U.S. bank holds cross-border claims in ranges from 1 to 58, with a median of 8 countries. About 25 percent of observations come from 'specialized' banks, i.e., those with 4 or fewer target host countries. Onequarter of U.S. banks also hold local (affiliate) claims in host countries they maintain a cross-border banking relationship with. For these U.S. banks, the number of affiliate-active countries ranges from 1 to 15, with a median of 6 countries. About 25 percent of the observations on affiliate claims come from U.S. banks which are quite 'specialized', with 3 or fewer affiliate-active countries. As will become clear below, we demonstrate that our results are robust to removing the "specialized" banks from our sample.

\section{3.b. Data on U.S. banks' balance sheet and financial conditions}

Our bank-level (supply-side) control variables come from the quarterly balance sheet and financial database collected from the Report of Condition and Income (Call Reports). ${ }^{13}$ We include the following bank-specific variables in our regressions: total assets, capital to asset ratio, deposit to asset ratio, return on equity and the expense ratio. In order to control for reporting biases, we also calculate a Selection Correction statistic from logistic regressions of a bank's globally active/non-active status (for Equation 1), and foreign market presence status (for Equation 2). In doing so, we follow the methodology proposed by Dubin and Douglas (1990). The details of the logistic specifications are presented in the Appendix.

${ }^{13}$ Call Reports data are reported on the FFIEC Central Data Repository's Public Data Distribution site (for commercials banks), on the FR Y-9C forms on the Chicago Fed's website (for bank holding companies) and on the FR 2886b and FFIEC 002 forms (for Edge and Agreement Corporations). 


\section{3.c. Data on U.S. and host country monetary and macro characteristics}

In some specifications of our estimation of local (affiliate) bank flows and foreign affiliate presence, we also include a set of host country macroeconomic characteristics to control for time-variant changes in demand conditions. We focus on the following set of controls: Quarterly change in the host country's short-term interest rate, the exchange rate and the host country's GDP. ${ }^{14}$ Data on these variables come from the IMF's International Financial Statistics, OECD's Statistics and the EIU's Country Data. Data on the U.S. target Fed funds rate and the Fed's holdings of U.S. Treasury securities comes from the website of the Federal Reserve. The dataset on post-crisis shadow short term interest rate is constructed, documented and provided by Krippner (2013). The crisis indicator variable, included in some post-crisis specifications, is defined to equal 1 from the first quarter of 2008 through the end of 2009, and to equal 0 otherwise. Table 1 provides detailed data descriptions, sources, and summary statistics.

\section{Estimation Results}

We present our estimation results in Tables 2 through 7. In Table 2, we estimate Equation (1) using the maturity-specific cross-border bank flows dataset, identifying the role of U.S. monetary policy shocks using the deposit to assets ratio as the bank liquidity measure. We then repeat the same exercise, using the capital to asset ratio as our funding constraint measure in Table 3. We then move on to examine the bank lending channel using the sector-specific version of our cross-border bank flows dataset in Table 4using both the deposit to asset and capital ratios as measures of bank funding constraints. While in

\footnotetext{
${ }^{14}$ In the affiliate lending flows regressions, the inclusion of exchange rate changes and Host Country - Time Fixed Effects controls for valuation effects in lending flows. Exchange rate changes are not directly addressed in crossborder lending, since these flows are more likely denominated in U.S. dollars.
} 
Tables 2 through 4 we focus our attention on the pre-crisis period, in Table 5 we examine the role of the Fed's unconventional monetary policy actions after the onset of the crisis in determining U.S. banks' cross-border flows. In Table 6, we explore how the impact of U.S. monetary policy differs between the higher and lower income host countries in our sample. Lastly, in Table 7 we study the role of U.S. and host country monetary policy shocks in driving U.S. banks' local (affiliate) flows in foreign countries.

\section{Cross-Border Flows}

Table 2 shows that there is strong evidence of a global bank lending channel in U.S. banks' cross-border changes in exposures in the 2003-2007 period. As we move from Column 1 to 4 , we include an increasingly exhaustive set of fixed effects to control for non-monetary shocks and unobservable factors. The results in Table 2 indicate that an impact of a 100 basis points decrease in the U.S. Fed funds rate causes a cumulative 6.12 to 7.66 percentage points increase in bilateral cross-border flows. ${ }^{15}$

Importantly, the coefficients on the interaction of the U.S. Fed funds rate change and the bank's liquidity (deposit to asset) ratio is highly significant throughout. Therefore, the bilateral cross-border flows of more liquidity-constrained U.S. banks are affected by U.S. monetary policy significantly more than the flows of their liquidity-abundant counterparts, suggesting a causal role for U.S. monetary policy. In fact, the percentage change in U.S. cross-border lending across countries and credit maturities following a 100 basis points decrease in the U.S. Fed funds rate is 3.08 to 5.18 percentage points higher for illiquid banks (at the $25^{\text {th }}$ percentile of liquidity distribution) than liquid banks (at the $75^{\text {th }}$ percentile of liquidity). ${ }^{16}$

\footnotetext{
15 A 100 basis points change in the Fed Funds rate corresponds to an approximately two standard deviation change. While the Fed generally changes interest rates in 25 basis points increments, a particular monetary policy goal (tightening or easing) is generally achieved in several steps. Since we are examining the cumulative effects of monetary policy actions over four quarters, we present results in response to a $100 \mathrm{bps}$ change in the interest rate. The mean change in cross-border flows during the pre-crisis period equals 2.76 percent, with a standard deviation of 42.98.

${ }^{16}$ Cross-border lending flows are generated out of the funds of banks' domestic (US) offices, which are exposed to US monetary policy-induced funding shocks. Therefore, host country interest rate changes are not included in the
} 
As mentioned above, about 25 percent of observations in the sample come from U.S. banks that are specialized lenders, i.e., make cross-border investments in 4 or fewer countries. The inclusion of these banks in the sample may bias our results, since the bilateral cross-border flows of these specialized banks may be strongly affected by historical, cultural or ownership ties (Paravisini, Rappoport and Schnabl (2014)). Therefore, in Columns 5 through 9 we focus our attention on multi-country lenders, i.e., banks with 5 or more bilateral cross-border relationships. We find that the coefficient on the interaction of bank liquidity and U.S. monetary shocks remains highly significant, even with the inclusion of increasingly exhaustive sets of fixed effects. Liquidity-constrained U.S. banks increase their bilateral cross-border flows by 2.79 to 4.76 percentage points more than their liquidity-abundant counterparts in response to a 100 basis points decrease in the Fed funds rate.

In Columns 10 and 11, we examine how our results on the presence on an active international bank lending channel may vary depending on the maturity of cross-border flows. We expect that quarterly monetary policy shocks have a stronger impact on short-term claims than long-term flows, as the former are easier to adjust depending on liquidity conditions. Indeed, the coefficient on the liquidity and monetary shock interaction is significant at the 5 percent level in short-term flows. Furthermore, liquidity-constrained banks' short-term cross-border flows respond 5.33 percentage points more to a 100 basis points decrease in the Fed funds rate than the flows of their liquidity-abundant counterparts. In auxiliary regressions, we also explore how monetary policy affects the maturity composition of crossborder lending, ${ }^{17}$ and find that monetary tightening in the US causes a significant shift towards shortterm maturities in US banks' cross-border flows. Furthermore, this monetary policy-induced shift towards short-term flows is significantly greater for liquidity-constrained US banks. The result that

cross-border specifications. The choice to do so is validated by the finding that our US monetary transmission results are robust to the inclusion of Host Country - Time Fixed Effects (which would pick up any impact that host country interest rate changes may have on cross-border lending flows). When we repeat Models 4 and 9 of Table 2 including host country interest rate changes in a robustness check, we find that these variables enter the regressions insignificantly while the US monetary policy effects remain significant.

${ }^{17}$ Detailed results are available from the authors upon request. 
funding-constrained banks add more cross-border claims, ${ }^{18}$ all else equal, apparent through Table 2, is consistent with the findings of Temesvary (2014).

In Table 3, we repeat the same specifications as in Table 2 using the capital ratio as our measure of a bank's ability to obtain outside funding. These results also show convincing evidence of an international bank lending channel in cross-border flows. Throughout the table, the monetary policy effects are greater in magnitude than those we obtained using the deposit to asset ratio as the funding constraint measure. While the full-sample specifications in Columns 1 through 4 exhibit weaker results, the monetary policy coefficients become highly significant when we control for the confounding effects of specialized lender banks in Columns 5 through 9. These results indicate that a 100 basis points decrease in the U.S. Fed funds rate leads to a 9.72 to 19.64 percentage points increase in bilateral cross-border lending flows, and this impact is significantly higher for less-capitalized U.S. banks. Depending on the specification, a 100 basis points decrease in the Fed funds rate causes a 4.10 to 8.20 percentage points greater increase in cross-border flows by low-capitalized banks than high-capitalized ones. Looking by maturity, we observe a similar result as in Table 2: Short-term flows exhibit a much stronger response to monetary shocks than do long-term investments. The coefficient on the interaction of the monetary shock and the capital ratio is positive and significant at the 1 percent level: Low-capitalized U.S. banks exhibit a 2.28 percentage points greater response to U.S. monetary policy shocks than high-capitalized ones.

Table 4 repeats specifications (1) through (4) from both Tables 2 and 3, now using the dataset on the sector-specific cross-border lending flows (to the financial, private and the public sectors of host countries). We continue to see strong evidence of an international bank lending channel, using either the deposit to asset ratio in Columns (1) through (4) or the capital ratio in Columns (5) through (8) as our liquidity measure. Looking at the results using the deposit to assets ratio, the coefficients on the

\footnotetext{
${ }^{18}$ Low-capitalized banks are also significantly bigger (in terms of asset size) than their high-capitalized counterparts.
} 
interaction terms of bank liquidity and monetary shocks are positive and significant at the 1 percent level. This corresponds to a 2.34 to 3.08 percentage points higher increase in cross-border flows by lowliquidity banks than liquid ones, in response to a 100 basis points decrease in the Fed funds rate.

Using the capital ratio as our measure of bank funding constraints in Columns (5) through (8), the direct effect of a 100 basis points decrease in the Fed funds rate is a 3.66 to 4.43 percentage points increase in bilateral cross-border flows. This impact is significantly higher for low-capitalized banks: A bank at the $25^{\text {th }}$ percentile of the capital ratio distribution responds by 0.63 to 1.07 percentage points more to a 100 basis points decrease in the Fed funds rate than does a high liquidity bank. All the monetary policy effects in Columns (5) through (8) are significant at the 1 percent level - even when the model is saturated with the most exhaustive set of fixed effects (including bank controls, bank - host country sector and time fixed effects). The breakdown of the results by sector (Columns 9 through 11) illustrates that the monetary transmission results are the strongest (both in terms of magnitude and significance) in lending to the non-financial private sector, followed by lending to the financial private sector. As expected, the monetary transmission effects are negligible in lending to the public (sovereign) sectors of foreign countries. Overall, the results in Tables 2 through 4 demonstrate a robust relationship between U.S. monetary policy and cross-border flows. The stronger impact for funding constrained banks is consistent with a causal role for U.S. monetary policy.

\section{Post-2007 Period}

Our analysis thus far has focused on the time period before the onset of the financial crisis and the pursuant recession. In Table 5, we examine the presence of the international bank lending channel in the post-2007 period. ${ }^{19}$ Due to the low number of post-crisis observations and the confounding effects of

\footnotetext{
19 In addition to splitting the data into pre-crisis and post-2007 subsamples, we also repeat the Table 2 specifications using the full sample, replacing the Fed Funds Rate with the Krippner (2013)'s Shadow Short-term
} 
aggregate shocks during the crisis, previous work on the international bank lending channel was limited to simple pre vs post-crisis-onset comparative analysis regarding the post-2007 period. However, our dataset reaches up to the first quarter of 2013 - including a sufficient number of time periods in the aftermath of the onset of the crisis to allow for a study of global monetary transmission comparable to the pre-crisis analysis. ${ }^{20}$ Similar to Cetorelli and Goldberg (2012), we define the onset of the crisis episode in international banking to take place in the first quarter of 2008 - shortly before the onset of the main events of the U.S. financial crisis.

Two important complications in studying the post-2007 period in U.S. banks' global activities are the presence of aggregate shocks which simultaneously affected the demand and supply sides of international financial flows, and the increasing irrelevance of the Fed funds rate as a measure of the stance of U.S. monetary policy. First, the quick contagion of the financial crisis across institutions and borders caused leftward shifts in the supply of credit. Soon thereafter, the real economic effects brought on by the drying-up of liquidity led to leftward shifts of the world-wide demand for credit as well, while central banks around the world engaged in aggressive expansionary policy to fend off these negative economic effects. To sum up: Substantial drops in interest rates coincided with large decreases in the volume of bank credit.

In our Table 5 analysis of the post-2007 period, we rely on an extensive set of fixed effects to separate these aggregate shocks from changes in flows brought on by monetary easing. In all our specifications, we include bank controls, bank-host country-maturity or bank- host country-sector fixed effects and time fixed effects. Where possible, we also include a crisis indicator variable for the 2008-2009 periods. Furthermore, as before, we include four lagged values of our monetary measures and present cumulative marginal effects in Table 5.

Rate as the measure of US monetary policy stance throughout (we discuss this Rate in a few paragraphs). We find that our results on global monetary transmission remain significant in this pooled specification.

${ }^{20}$ Our dataset covers 20 periods in the pre-crisis era, and 21 periods (time-quarters) since the onset of the crisis. 
The second issue to tackle is the irrelevance of the Fed funds rate as a monetary measure in the post2007 period. In December 2008, the Fed's aggressive expansionary efforts sent the effective Fed funds rate below 25 basis points. This policy rate remained at near-zero levels throughout the remainder of our sample, while the Fed's active monetary expansion continued. As a result, quarterly changes in the Fed funds rate are no longer informative measures of the stance of U.S. monetary policy in the post-2007 period. Instead, we examine two alternate measures of the stance of U.S. monetary policy for our post2007 analysis.

First, we employ Krippner (2013)'s shadow short-term interest rate in place of the Fed funds rate (Columns 1 through 4). ${ }^{21}$ Our second proxy for unconventional monetary policy is the Fed's sales of Treasury Securities (Columns 5 through 8 ). ${ }^{22}$ In Columns (1), (2), (5) and (6), we use the maturitybreakdown cross-border flows data, while in Columns (3), (4), (7) and (8) we use the sectoral-breakdown data. For both types of data and monetary policy measures, we examine both the deposit to asset ratio and the capital ratio as measures of bank funding constraints.

Using Krippner (2013)'s shadow short-term rate as our measure of monetary policy in the first four columns of Table 5, we find significant monetary policy effects using the capital ratio as our constraint measure (Columns 2 and 4). In these specifications, low-capitalized U.S. banks (at the $25^{\text {th }}$ percentile of capital distribution) raise their cross-border flows 2.8 to 3.4 percentage points more than their highcapitalized counterparts, in response to a 100 basis points decrease in Krippner's short-term shadow rate..$^{23}$ These effects are economically relevant as average cross-border flows were 0.66 percent in the post-2007 period (with a standard deviation of 37.71). The results hold up using either the sectoral or

\footnotetext{
${ }^{21}$ The construction of this shadow short term rate is carefully documented and explained in Krippner (2013).

${ }^{22}$ We use the Fed's sale, as opposed to purchases, of securities ensures that increases in the monetary measure correspond to contractionary policy, while decreases are indicative of expansionary policy. This makes our measure of unconventional monetary policy is consistent with the use of the Fed's funds rate in the pre-crisis period.

${ }^{23}$ A 100 basis points change in the Shadow Short-term Rate corresponds to approximately two standard deviations.
} 
maturity-breakdown data and including an exhaustive set of demand and supply-side fixed effects to control for aggregate shocks. ${ }^{24}$

In Columns (5) through (8), we repeat the specifications of (1) through (4), now using the Fed's sale of Treasury securities as our measure of monetary policy. Previously, our unit of measurement was a 100 basis points change in the base interest rate - which corresponds to an approximately 2 standard deviations change in the case of the Krippner short-term shadow rate. For consistency, we define a unit change in the Fed's sale of securities as a two standard deviations change in this measure as well. This corresponds to an approximately 30 percentage points change in this variable. While there is no evidence of substantial monetary transmission in the maturity-breakdown data (Columns 5 and 6), we find significant monetary effects in the sector-specific data (Columns 7 and 8 ) even after saturating the model with a full set of fixed effects. Using the deposit to asset ratio as our measure of bank liquidity, we find that low-liquidity banks increase their bilateral cross-border flows in response to a 30 percentage points increase in the Fed's purchases of Treasury securities (quantitative easing) by 0.74 to 8.70 percentage points more than banks with high liquidity. These results are significant at the 5 percent or 1 percent, even in the presence of an exhaustive set of host country-bank-sector and time fixed effects and bank-level controls.

\section{Higher vs. Lower Income Host Countries}

Our results so far have shown that U.S. monetary policy is associated with changes in cross-border flows, especially for funding constrained banks. While we have controlled for a large number of bank, host country characteristics, and fixed effects, there still may be additional variation in our host country characteristics that explains the U.S. bank response. We take one step towards exploring that variation

\footnotetext{
${ }^{24}$ An important characteristic of the post-2007 period was the rapid build-up of excess reserves on banks' balance sheets. The implication of this phenomenon is that banks only turned a fraction of the liquidity provided by the Fed into loans in the post-2007 period. Therefore, the buildup of excess reserves actually makes our results on the strength of the bank lending channel seem conservative.
} 
by including a dummy variable for lower income countries (below the median income per capita in the given time period) and interacting it with U.S. monetary policy measures. The results of that estimation appear in Table 6. Columns 1 and 2 of Table 6 replicate the specifications in Column 4 from Tables 2 and 3 with the addition of a lower income dummy variable and its interaction with the key monetary policy variables. Columns 3 and 4 in Table 6 replicate Columns 4 and 8 of Table 4, while Columns 5 through 8 of Table 6 replicate the post-crisis specifications in Columns 1 through 4 of Table 5 in a similar way.

Table 6 reveals that by allowing for the bank response to vary for lower vs. higher income countries, our earlier results are even stronger. Columns 1 through 4 show that in the pre-crisis period, the differential between the responses of low- vs. high-capitalized banks' flows to changes in U.S. monetary policy is significantly greater in lower income countries than higher income countries in three out of the four specifications. In fact, this differential between the monetary policy responses of low- vs. high -capitalized banks' flows to lower income countries is 0.22 to 0.48 percentage points greater than the differential measured in flows to high income hosts. Focusing on the post-2007 period, a comparison of the first four columns of Table 5 and Columns 5 through 8 of Table 6 also suggests that it is important to allow for the U.S. bank response to vary by income level of the host country. In three out of the four post-2007 specifications, low-capitalized banks' flows to high income countries decreases 0.31 to 0.68 percentage points more in response to a 100 basis points increase in the U.S. Fed funds rate than those of their high-capitalized counterparts. Furthermore, this differential between the responses of low vs. high-capitalized banks' flows to monetary policy is 0.04 to 0.94 percentage points lower in lower income countries than in their higher income counterparts. Overall, these results indicate that cross-border bank flows by U.S. banks do respond to changes in U.S. monetary policy, and this response differs across lower vs. higher income host countries. ${ }^{25}$

\footnotetext{
${ }^{25}$ The data reveals that US banks are significantly less active in lower-income countries: these countries receive flows from a median of 5 US banks, while this number is as high as 11 for higher-income countries. Therefore, this
} 
Affiliate flows

In Table 7, we study the impact of U.S. monetary policy on the local (affiliate) flows of U.S. banks in foreign countries. Previous papers found a strong positive impact of U.S. monetary easing on the foreign affiliate flows of U.S. banks in both the pre-crisis (Cetorelli and Goldberg (2012)) and post-crisis (Morais, Peydró and Ruiz (2015)) periods. Because our local flows data incorporates claims by affiliates who operate as fully chartered subsidiaries in foreign countries, we also expect that provision of liquidity by the host country's monetary authority (as measured by quarterly changes in the host's short-term base rate) would also significantly impact U.S. banks' local flows there. However, we also expect that the extent of host country monetary influence is directly related to the prevalence of the local (host country) currency in U.S. banks' investments there. In Columns (1) through (4), we study the role of U.S. and host country monetary conditions on U.S. banks' local flows via affiliates. In Columns (5) through (8), we then focus on the subset of the local flows of multi-country (non-specialized) U.S. banks in lowly-dollarized countries (i.e., where the share of dollar-denominated claims is below the $40^{\text {th }}$ percentile across all countries). Throughout Table 7, we control for changes in host country macro traits, the bias inherent in selective reporting, and an increasingly exhaustive set of demand and supply-side fixed effects.

In our full sample specifications in Columns (1) through (4), we find evidence that host country monetary policy matters, but no support for a role for U.S. monetary policy in determining U.S. banks' foreign affiliate flows. The direct impact of a decrease in host country short-term interest rates on local flows is positive, and significantly more so for low-capitalized U.S. banks. A positive impact of a 100 basis points decrease in the host country interest rate on local flows is 1.86 to 3.88 percentage points higher for lowcapitalized U.S. banks' affiliates than for those of high-capitalized U.S. banks. ${ }^{26}$ These effects are

exercise in differentiating monetary policy effects along the host country income dimension can also be interpreted as an examination of monetary policy effects across host countries with higher US bank presence vs. lower US bank presence.

${ }^{26}$ A 100 basis points change in host country interest rates corresponds to a one-third standard deviation change. 
economically relevant given that the average affiliate flows were equal to 0.68 percent during the sample period (with a standard deviation of 19.43). The significance and magnitude of the difference between the funding-constrained vs. unconstrained banks` monetary effects remains high even after we saturate our model with host country-time and bank fixed effects. The coefficients on both the levels and interactions of U.S. monetary policy changes are insignificant in all our Table 7 specifications.

We expect that the host country monetary policy effects are particularly strong in those foreign countries where the majority of U.S. banks' local claims are denominated in the country's currency (i.e., the currency in which the monetary authority provides liquidity to banks). In line with expectations, our results on the role of host country monetary policy increase in magnitude once we restrict our attention to the subset of multiple-country U.S. banks in lowly-dollarized countries (while the U.S. monetary effects remain insignificant). The direct effect of a 100 basis points decrease in the host country monetary policy rate is as much as a 16.21 percentage points rise in local flows (Column 5 ). The positive monetary impact is a significant 12.41 to 13.95 percentage points higher for low-capitalized U.S. banks than for high-capitalized ones. The significance of our monetary results disappears once we fully control for demand-side conditions in Columns (7) and (8). This, however, could be due to the fact that our sample size drops substantially (by two-thirds) once we move to our restricted sample.

Notably, we find no evidence on the existence of a bank lending channel of U.S. monetary policy in banks' foreign affiliate flows. At first blush, this result appears to be at odds with the findings of recent papers on the topic. Morais, Peydró and Ruiz (2015) find a strong bank lending channel of U.S. monetary policy in the local flows of U.S. banks in Mexico, while Coleman, Correa, Feler and Goldrosen (2014) find that even the flows of non-U.S. affiliate private banks in Brazil are affected by U.S. monetary policy. We can point to four potential sources as to the discrepancy of our results. First, we saturate our specifications with increasingly exhaustive sets of fixed effects to control for demand-side conditions 
over time. If previous findings of a bank lending channel in local flows were due to rightward shifts in the demand for U.S. bank claims in host countries that coincided with U.S. monetary policy easing, then our explicit controls for demand-side shifts would negate these findings. ${ }^{27}$ Second, we include in our specifications changes in the host country's monetary policy rate, both in its level and interaction with bank liquidity. To the extent that foreign monetary policy rates move together with U.S. policy rates, previous work's findings on the significant impact of U.S. monetary policy on local flows might have been due to an omitted variable problem. The last two possible explanations pertain to limitations of our dataset. Specifically, the local flows data we construct is based on net local claims. If local claims rise in tandem with local liabilities in response to a U.S. monetary expansion, net claims would remain unchanged even if gross claims were rising. Lastly, a limitation of our estimation is that our identification is based on the use of the headquarters ' (U.S.) capitalization of the bank - we do not have data on the capitalizations and liquidity conditions of individual subsidiaries.

\section{The Extensive Margin}

In Tables A.1 and A.2 in the Appendix, we examine the role of U.S. monetary policy on the extensive margin: How changes in the U.S. Fed funds rate affected U.S. banks' choice to become globally active (Table A.1) and to establish local presence in a given foreign country (Table A.2). It is those estimations we used in the previous Tables to control for selection into the set of globally active banks (Table A.1) and affiliate-active host markets (Table A.2).

In Table A.1, we use a large dataset including the balance sheet and financial data of all U.S. financial institutions over the 2003-2007 period. Our dependent variable of interest is an indicator that takes on a value of 1 if the bank operates beyond U.S. borders in the given period, and 0 otherwise. In a set of logistic specifications described in the Appendix, we examine how this globally active vs. non-active

${ }^{27}$ However, Coleman, Correa, Feler and Goldrosen (2014) 's findings are robust to controlling for demand-side changes. 
status depends on the stance of U.S. monetary policy, while controlling for an exhaustive set of supplyside conditions (details of the specifications are shown in the Appendix). Regarding the role of monetary policy, a 100 basis points decrease in the U.S. Fed funds rate was associated with a 0.30 to 1.21 percentage points increase in the probability of a U.S. bank maintaining global operations in the precrisis period. Given that the sample probability is 3.74 percent, these are economically meaningful effects. There is no significant difference between low vs. high-capitalized banks in this impact of U.S. monetary policy. Table A.1 reveals that whether the bank was globally active in the previous period is a very strong predictor of its current globally active status. Bigger banks with lower capitalization are more likely to be active abroad. U.S. banks are also more likely to maintain global operations during periods of economic expansion.

In Table A.2, we focus again on the subset of globally active U.S. banks as in Tables 2 through 6 . In these specifications, we examine any impact that the stance of U.S. monetary policy might have had on U.S. banks' choice to maintain local operations in a given host market in the pre-crisis period. There is some evidence that changes in the U.S. Fed funds rate affect this decision: Its level effect is significant in two of the four specifications (including our most saturated model in Column 4). The interaction of monetary policy changes with bank capitalization is significant in our two most saturated specifications (Columns 3 and 4). Therefore, there is some evidence that decreases in the U.S. Fed funds rate contribute to U.S. banks' likelihood of adding a local presence in a foreign country that it already maintains a cross-border relationship with. These effects remain even after controlling for host country macro controls and host country and bank fixed effects. However, the strongest predictors of this decision appear to be bank size and whether the bank already maintained local presence in the country in the previous period. Both these variables have positive and strongly significant effects on local presence probability. 


\section{Summary and Conclusion}

In this paper, we studied the functioning of the bank lending channel through the foreign financial flows of U.S. banks via external capital markets between 2003 and 2013. Specifically, we examined how changes in the stance of U.S. monetary policy (as changes in the Fed funds rate up to 2007, and quantitative easing beyond) affected U.S. banks' bilateral cross-border and foreign affiliate flows. Using the identification strategy that funding-constrained banks exhibit a stronger response to changes in liquidity conditions than their unconstrained peers, we find strong evidence that U.S. monetary easing significantly increased the bilateral cross-border flows of U.S. banks in the pre-crisis period, and this effect was substantially stronger for constrained banks. We also find some evidence that unconventional monetary policy (quantitative easing) in the post-crisis period was significantly and positively related to bilateral cross-border flows by U.S. banks. Furthermore, the impact of U.S. monetary policy both pre and post-crisis varies across lower vs. higher income countries. These findings are robust to various data specifications, funding constraint measures (i.e., deposit or capital to assets ratios) and the inclusion of exhaustive sets of relevant fixed effects. Some results suggest that the extra liquidity provided by expansionary U.S. monetary policy also contributed to U.S. banks' decision to "go global" and to establish local presence in foreign countries.

Our contributions to the literature are three-fold. First, our bilateral financial flows data allows us to explicitly control for changing conditions in the demand for investment by U.S. banks abroad, thereby providing a clearer identification of the bank lending channel (Bernanke and Gertler (1995)). Second, to our knowledge our work is the first to document the working of the bank lending channel through U.S. banks' cross-border flows in external capital markets, i.e., to non-affiliated parties abroad. By doing so, our results complement the findings of Cetorelli and Goldberg (2012) on the bank lending channel in U.S. banks' internal capital markets abroad and Morais, Peydró and Ruiz (2015)'s work on the lending channel 
in U.S. banks' foreign affiliate lending abroad. Third, we are able to study the periods before and after the onset of the financial crisis using comparable empirical models, and establish the strong positive impact of quantitative easing on U.S. banks' foreign flows.

There is intensifying policy interest in the mechanics of the cross-border spillovers of domesticallyoriented macroeconomic policies and their feedback effects on national economies. As Stanley Fischer expressed in 2014: "[T]he U.S. economy and the economies of the rest of the world have important feedback effects on each other. To make coherent policy choices, we have to take these feedback effects into account." In this context, our findings on the prevalence of the bank lending channel in U.S. banks' foreign flows moves the study of these spillover effects forward. 


\section{References}

Bernanke, Ben S., and Alan S. Blinder, 1992, The federal funds rate and the channels of monetary transmission, American Economic Review 82, 901-921.

Bernanke, Ben S., and Mark Gertler, 1995, Inside the black box: The credit channel of monetary policy transmission, Journal of Economic Perspectives 9, 27-48.

Cerutti, Eugenio, Stijn Claessens, and Lev Ratnovski, 2014, Global liquidity and drivers of cross-border bank flows, International Monetary Fund, Washington DC, Mimeo

Cerutti, Eugenio, Galina Hale, and Camelia Minoiu, 2015, Financial crises and the composition of crossborder lending, Journal of International Money and Finance 52, 60-81.

Cetorelli, Nicola, and Linda S. Goldberg, 2011, Global banks and international shock transmission: Evidence from the crisis, IMF Economic Review 59, 41-76.

Cetorelli, Nicola, and Linda S. Goldberg, 2012, Banking globalization and monetary transmission, Journal of Finance 67, 1811-1843.

Cetorelli, Nicola, and Linda S. Goldberg, 2012, Liquidity management of U.S. Global banks: Internal capital markets in the great recession, Journal of International Economics 88, 299-311.

Coleman, Nicholas, Ricardo Correa, Leo Feler, and Jason Goldrosen, 2014, Unconventional monetary policy spillovers and local credit provision, Federal Reserve Board, Washington DC, Mimeo

Dinger, Valeriya, and Daniel Marcel te Kaat, 2015, Global imbalances and bank risk-taking, University of Osnabrück, Osnabrück, Mimeo

Dubin, Jeffrey A., and Rivers Douglas, 1990, Selection bias in linear regression, logit and probit models, Sociological Methods and Research 18, 360-390.

Fischer, Stanley, 2014, The federal reserve and the global economy, Per Jacobsson Foundation, Washington DC, Lecture

Goldberg, Linda S. , 2007, Financial sector FDI and host countries: New and old lessons, Federal Reserve Bank of New York Economic Policy Review 13, 1-17.

He, Dong, and Robert N. McCauley, 2013, Transmitting global liquidity to East Asia: Policy rates, bond yields, currencies and dollar credit, Bank for International Settlements, Basle, Working Paper 431.

loannidou, Vasso P., Steven Ongena, and José-Luis Peydró, 2014, Monetary policy, risk-taking and pricing: Evidence from a quasi-natural experiment, Review of Finance Forthcoming.

Jiménez, Gabriel, Steven Ongena, José-Luis Peydró, and Jesús Saurina, 2012, Credit supply and monetary policy: Identifying the bank balance-sheet channel with loan applications, American Economic Review 102, 2301-2326.

Kashyap, Anil K., and Jeremy C. Stein, 2000, What do a million observations on banks say about the transmission of monetary policy?, American Economic Review 90, 407-428.

Krippner, Leo, 2013, Documentation for United States measures of monetary policy, Reserve Bank of New Zealand Wellington, Mimeo

Lo Duca, Marco, Giulio Nicoletti, and Ariadna Vidal Martinez, 2014, Global corporate bond issuance: What role for US quantitative easing?, European Central Bank, Frankfurt, Working Paper 1649.

McCauley, Robert N., Patrick McGuire, and Vladyslav Sushko, 2015, Global dollar credit: Links to US monetary policy and leverage, Economic Policy Forthcoming.

Morais, Bernardo, José-Luis Peydró, and Claudia Ruiz, 2015, The international bank lending channel of monetary policy rates and quantitative easing: Credit supply, reach-for-yield, and real effects, World Bank, Washington DC, Working Paper 7216. 
Ongena, Steven, Ibolya Schindele, and Dzsamila Vonnák, 2015, In lands of foreign currency credit, bank lending channels run through? The effects of monetary policy at home and abroad on the currency denomination of the supply of credit, University of Zurich, Zurich, Mimeo

Paravisini, Daniel, Veronica Rappoport, and Philipp Schnabl, 2014, Comparative advantage and specialization in bank lending, London School of Economics, London, Mimeo

Peek, Joe, and Eric S. Rosengren, 1997, The international transmission of financial shocks: The case of Japan, American Economic Review 87, 495-505.

Temesvary, Judit, 2014, The determinants of U.S. Banks' international activities, Journal of Banking and Finance 44, 233-247. 
Table 1

Summary statistics

Dependent Variable

Quarterly Change in Cross-border US Bank Lending Aggregate (Pre-crisis)

Aggregate (Post-2007)

$\leq 1$ Year (Pre-crisis)

$\leq 1$ Year (Post-2007)

$>1$ Year (Pre-crisis)

$>1$ Year (Post-2007)

To Banks (Pre-crisis)

To Banks (Post-2007)

To Non-financial Private Sector (Pre-crisis)

To Non-financial Private Sector (Post-2007)

To Public Sector (Pre-crisis)

To Public Sector (Post-2007)

Quarterly Change in US Bank Affiliate Lending in Other Countries (Pre-crisis)

US Bank Maintains Affiliate in Host Country (Pre-crisis) the change in the natural logarithm of the bank's stock of total cross-border claims in the host country in quarter t pre-crisis

the change in the natural logarithm of the bank's stock of total cross-border claims in the host country in quarter $t$ post-2007

the change in the natural logarithm of the bank's stock of total cross-border claims with a remaining maturity below one year in the host country in quarter t pre-crisis

the change in the natural logarithm of the bank's stock of total cross-border claims with a remeng meturty below on year in the host country in quarter t post-2007

the change in the natural logarithm of the bank's stock of total cross-border claims with a remaining maturity equal to and above one year in the host country in quarter $t$ pre-crisis

the change in the natural logarithm of the bank's stock of total cross-border claims with a remaining maturity equl to and above one year in the host colty in qurter post to

the change in the natural logarithm of the bank's stock of total cross-border claims on the host country's financial sector in quarter t pre-crisis

the change in the natural logarithm of the bank's stock of total cross-border claims on the host country's financial sector in quarter t post-2007

the change in the natural logarithm of the bank's stock of total cross-border claims on the host country's non-financial private sector in quarter $t$ pre-crisis

the change in the natural logarithm of the bank's stock of total cross-border claims on the host country's non-financial private sector in quarter t post-2007

the change in the natural logarithm of the bank's stock of total cross-border claims on the host country's public sector in

quarter $t$ pre-crisis

the change in the natural logarithm of the bank's stock of total cross-border claims on the host country`s public sector in quarter $t$ post-2007

the change in the natural logarithm of the bank's stock of net foreign affiliate claims in the host country in quarter $t$ pre-crisis

indicator variable that equals 1 if the US bank maintains an affilite in the host country at time $t$, and equals 0 otherwise

\begin{tabular}{|c|c|c|c|c|c|c|c|c|c|c|}
\hline$\%$ & 2,981 & 2.76 & 42.98 & -199.80 & -40.55 & -11.51 & 0 & 18.23 & 47.00 & 194.59 \\
\hline$\%$ & 2,001 & 0.66 & 37.71 & -188.49 & -36.77 & -11.43 & 0 & 13.55 & 38.78 & 185.63 \\
\hline$\%$ & 1,781 & 1.96 & 42.55 & -199.24 & -40.55 & -11.33 & 0 & 16.43 & 46.44 & 205.59 \\
\hline$\%$ & 1,333 & -1.81 & 37.86 & -188.49 & -40.55 & -13.35 & 0 & 11.39 & 35.4 & 187.18 \\
\hline$\%$ & 1,754 & 0.43 & 28.66 & -173.46 & -14.8 & 0 & 0 & 0 & 17.93 & 203.69 \\
\hline$\%$ & 1,359 & 1.96 & 33.16 & -163.41 & -14.9 & 0 & 0 & 1.71 & 25.13 & 196.96 \\
\hline$\%$ & 2,285 & 1.09 & 43.87 & -180.39 & -47 & -9.53 & 0 & 13.32 & 49.48 & 199.24 \\
\hline$\%$ & 1,481 & -2.09 & 41.41 & -188.49 & -43.7 & -8.70 & 0 & 6.08 & 39.97 & 194.59 \\
\hline$\%$ & 2,297 & 1.30 & 35.61 & -180.18 & -22.31 & 0 & 0 & 4.45 & 29.73 & 186.21 \\
\hline$\%$ & 1,480 & 0.28 & 37.18 & -202.23 & -22.31 & -4.43 & 0 & 6.45 & 27.05 & 192.91 \\
\hline$\%$ & 2,289 & -0.46 & 16.17 & -130.59 & 0 & 0 & 0 & 0 & 0 & 151.98 \\
\hline$\%$ & 1,498 & -0.28 & 23.54 & -159.94 & 0 & 0 & 0 & 0 & 0 & 175.07 \\
\hline$\%$ & 1,588 & 0.68 & 19.43 & -176.34 & 0 & 0 & 0 & 0 & 2.93 & 195.04 \\
\hline $0 / 1$ & 1,807 & 0.11 & 0.32 & 0 & 0 & 0 & 0 & 0 & 1 & 1 \\
\hline
\end{tabular}




\section{Independent Variables}

Monetary Variables

US Federal Funds Rate (Pre-crisis)

$\Delta$ Host Country Short-Term Interest Rate (pre-crisis)

$\Delta$ US Krippner`s Shadow Short Rate (Post-2007)

$\Delta$ US Federal Reserve`s Sale of Securities (Post-2007)

Bank Variables

Bank Deposits to Assets Ratio

$\leq 1$ Year

$>1$ Year

Bank Capital Ratio

Bank Total Assets

Bank Return On Equity

Bank Cost Ratio

GDP Growth

US and Host Country CPI Inflation

Exchange Rate

Predicted Probability that US Bank Lends Across Borders

Predicted Probability that US Bank Maintains Affiliate in Host Country

Selection Bias Correction for Observing US Banks Lending Across Borders

Selection Bias Correction for Observing US Banks Affiliate Presence in Host Country

Financial Crisis (2008:Q1-2009:Q4)

Share of US Dollar-denominated Foreign Affiliate Claims in Total

Lower Income quarterly change in the US federal funds rate pre-crisis

quarterly change in the host country's short-term base interest rate pre-crisis

quarterly change in the Krippner (2013) US shadow federal funds rate post-2007

quarterly change in the Federal Reserve's sale of securities po

bank deposits divided by total assets

bank deposits (less than or equal to one year) divided by total

bank deposits (more than one year) divided by total assets

bank capital divided by total assets

the natural logarithm of total bank assets

bank net income divided by total equity

bank expenses divided by total assets

quarterly growth rate of Gross Domestic Product

quarterly change in the Consumer Price Index

quarterly change in the nominal exchange rate (expressed as the host country currency per US dollar)

predicted probability that the US bank lends across borders (i.e., reports on the FFIEC 009 form), derived from the logistic regression in Appendix Table 1

predicted probability that the US bank maintains an affiliate in the host country (i.e., reports non-zero affilite chein), derived the host country (i.e., repots nom-zero afrilte claims), derived

Selection Bias Correction statistic derived from the logistic regression in Appendix Table 1

Selection Bias Correction statistic derived from the logistic regression in Appendix Table 2

indicator variable that equals 1 between 2008:Q1 and 2009:Q4, and equals 0 otherwise.

ratio of all US banks' US Dollar-denominated foreign affiliate claims to total foreign affiliate claims in the host country

indicator variable that equals 1 if the host country is below the median GDP per capita across all host countries in that time

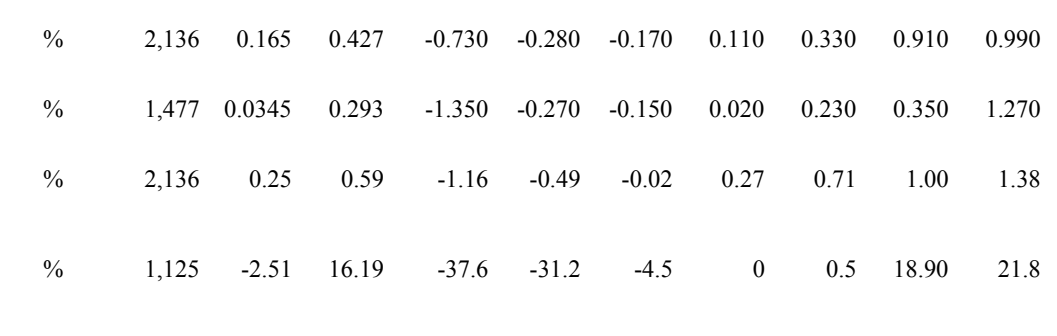

\begin{tabular}{|c|c|c|c|c|c|c|c|c|c|c|}
\hline$\%$ & 2,272 & 58.67 & 11.89 & 0.00 & 49.27 & 54.49 & 61.16 & 66.83 & 68.65 & 69.91 \\
\hline$\%$ & 1,571 & 23.00 & 16.73 & 0.00 & 3.76 & 6.65 & 22.18 & 34.91 & 43.11 & 68.34 \\
\hline$\%$ & 1,542 & 4.89 & 6.60 & 0.00 & 0.00 & 0.19 & 1.20 & 8.58 & 13.55 & 42.37 \\
\hline$\%$ & 2,136 & 9.13 & 5.88 & 0.00 & 4.05 & 6.29 & 7.82 & 10.62 & 15.38 & 44.83 \\
\hline mln. USD & 2,136 & 8.02 & 2.44 & -0.46 & 5.64 & 6.02 & 7.16 & 8.83 & 11.43 & 14.04 \\
\hline$\%$ & 2,136 & 5.99 & 9.84 & -46.33 & 0.69 & 2.18 & 4.77 & 8.69 & 11.84 & 126.20 \\
\hline$\%$ & 2,136 & 3.49 & 4.86 & 0 & 1.06 & 1.59 & 2.88 & 4.04 & 5.18 & 93.98 \\
\hline$\%$ & 1,847 & 3.85 & 2.94 & -6.46 & 1.26 & 2.06 & 3.32 & 4.81 & 7.52 & 36.06 \\
\hline$\%$ & 1,966 & 3.91 & 5.46 & -2.49 & 0.91 & 1.53 & 2.22 & 4.10 & 8.84 & 62.84 \\
\hline$\%$ & 2,018 & -3.75 & 9.05 & -46.77 & -12.53 & -8.9 & -4.94 & 0.13 & 7.50 & 59.50 \\
\hline$\%$ & 58,824 & 3.74 & 15.40 & 0 & 0 & 0.001 & 0.00 & 0.06 & 1.52 & 100 \\
\hline$\%$ & 1,807 & 12.78 & 26.93 & 0.017 & 0.70 & 1.20 & 2.30 & 5.97 & 76.98 & 99.59 \\
\hline - & 932 & 0.19 & 0.07 & 0 & 0.03 & 0.21 & 0.22 & 0.22 & 0.22 & 0.22 \\
\hline - & 1,807 & 1.49 & 0.58 & 1.21 & 1.25 & 1.25 & 1.26 & 1.29 & 2.22 & 3.75 \\
\hline $0 / 1$ & 1,519 & 0.69 & 0.46 & 0 & 0 & 0 & 1 & 1 & 1 & 1 \\
\hline$\%$ & 1,393 & 19.47 & 17.01 & 0 & 2.36 & 6.75 & 11.13 & 34.22 & 45.80 & 74.86 \\
\hline $0 / 1$ & 4,761 & 0.50 & 0.50 & 0 & 0 & 0 & 0 & 1 & 1 & 1 \\
\hline
\end{tabular}


Table 2

Quarterly change in cross-border US bank lending across countries and credit maturities for banks with different liquidity ratios during the 2003:Q1-2007:Q4 period

\begin{tabular}{|c|c|c|c|c|c|c|c|c|c|c|c|}
\hline Model & [1] & [2] & [3] & [4] & [5] & [6] & [7] & [8] & [9] & [10] & [11] \\
\hline Sample of Banks & All & All & All & All & $\begin{array}{l}\text { Multiple } \\
\text { Countries }\end{array}$ & $\begin{array}{l}\text { Multiple } \\
\text { Countries }\end{array}$ & $\begin{array}{l}\text { Multiple } \\
\text { Countries }\end{array}$ & $\begin{array}{l}\text { Multiple } \\
\text { Countries }\end{array}$ & $\begin{array}{l}\text { Multiple } \\
\text { Countries }\end{array}$ & $\begin{array}{l}\text { Multiple } \\
\text { Countries }\end{array}$ & $\begin{array}{l}\text { Multiple } \\
\text { Countries }\end{array}$ \\
\hline Included Maturities & All & All & All & All & All & All & All & All & All & $\leq 1$ Year & $>1$ Year \\
\hline$\Sigma \Delta$ US Federal Funds Rate $\{\mathrm{t}-1$ to $\mathrm{t}-4\}$ & $\begin{array}{c}-7.657 \\
{[3.574]^{* *}}\end{array}$ & $\begin{array}{c}-7.519 \\
{[3.362]^{* *}}\end{array}$ & $\begin{array}{l}-6.119 \\
{[4.228]}\end{array}$ & & $\begin{array}{c}-8.336 \\
{[1.139]^{* * *}}\end{array}$ & $\begin{array}{l}-6.670 \\
{[4.571]}\end{array}$ & & & & & \\
\hline$\Sigma \Delta$ US Federal Funds Rate $\{t-1$ to $t-4\} *$ Bank Deposits to Assets Ratio $\{t-1$ to $t-4\}$ & $\begin{array}{c}0.239 \\
{[0.082]^{* * *}}\end{array}$ & $\begin{array}{c}0.242 \\
{[0.077]^{* * *}}\end{array}$ & $\begin{array}{c}0.169 \\
{[0.059]^{* * *}}\end{array}$ & $\begin{array}{c}0.141 \\
{[0.062]^{* *}}\end{array}$ & $\begin{array}{c}0.144 \\
{[0.052]^{* * *}}\end{array}$ & $\begin{array}{c}0.208 \\
{[0.090]^{* *}}\end{array}$ & $\begin{array}{c}0.173 \\
{[0.093]^{*}}\end{array}$ & $\begin{array}{c}0.128 \\
{[0.048]^{* * *}}\end{array}$ & $\begin{array}{c}0.231 \\
{[0.038]^{* * *}}\end{array}$ & $\begin{array}{c}0.262 \\
{[0.119]^{* *}}\end{array}$ & $\begin{array}{c}0.262 \\
{[0.298]}\end{array}$ \\
\hline$\Sigma$ Bank Deposits to Assets Ratio $\{\mathrm{t}-1$ to $\mathrm{t}-4\}$ & $\begin{array}{l}-0.002 \\
{[0.025]}\end{array}$ & $\begin{array}{c}-0.002 \\
{[0.023]}\end{array}$ & $\begin{array}{l}-0.097 \\
{[0.130]}\end{array}$ & $\begin{array}{c}-0.177 \\
{[0.163]}\end{array}$ & $\begin{array}{c}-0.094 \\
{[0.043]^{* *}}\end{array}$ & $\begin{array}{c}-0.057 \\
{[0.130]}\end{array}$ & $\begin{array}{c}-0.069 \\
{[0.113]}\end{array}$ & $\begin{array}{c}-0.100 \\
{[0.039]^{* * *}}\end{array}$ & $\begin{array}{c}0.003 \\
{[0.133]}\end{array}$ & $\begin{array}{c}0.108 \\
{[0.081]}\end{array}$ & $\begin{array}{c}-0.247 \\
{[0.028]^{* * *}}\end{array}$ \\
\hline Constant & $\begin{array}{c}36.411 \\
{[12.769]^{* * *}}\end{array}$ & $\begin{array}{c}39.264 \\
{[24.012]}\end{array}$ & $\begin{array}{c}43.352 \\
{[32.044]}\end{array}$ & $\begin{array}{c}68.999 \\
{[51.879]}\end{array}$ & $\begin{array}{c}78.567 \\
{[41.575]}\end{array}$ & $\begin{array}{c}5.463 \\
{[12.134]}\end{array}$ & $\begin{array}{c}12.008 \\
{[14.128]}\end{array}$ & $\begin{array}{c}115.695 \\
{[147.214]}\end{array}$ & $\begin{array}{c}8.163 \\
{[9.220]}\end{array}$ & $\begin{array}{l}-1.827 \\
15.750]\end{array}$ & $\begin{array}{c}11.15 \\
{[10.020]}\end{array}$ \\
\hline$\overline{\text { Bank Controls }}$ & Yes & Yes & Yes & Yes & Yes & Yes & Yes & Yes & Yes & Yes & Yes \\
\hline Host Country - Bank Fixed Effects & Yes & Yes & -- & -- & Yes & No & No & Yes & No & No & No \\
\hline Credit Maturity Fixed Effects & No & No & -- & -- & Yes & -- & -- & Yes & -- & -- & -- \\
\hline Host Country - Credit Maturity Fixed Effects & No & No & -- & -- & No & Yes & Yes & No & -- & -- & -- \\
\hline Host Country - Bank - Credit Maturity Fixed Effects & No & No & Yes & Yes & No & No & No & No & No & No & No \\
\hline Time Fixed Effects & No & No & No & Yes & No & No & Yes & Yes & -- & -- & -- \\
\hline Time - Host Country Fixed Effects & No & No & No & No & No & No & No & No & -- & Yes & Yes \\
\hline Time - Host Country - Credit Maturity Fixed Effects & No & No & No & No & No & No & No & No & Yes & $\mathrm{n} / \mathrm{p}$ & $\mathrm{n} / \mathrm{p}$ \\
\hline Selection Bias Correction for Observing US Banks Lending Across Borders & No & Yes & Yes & Yes & Yes & Yes & Yes & Yes & Yes & Yes & Yes \\
\hline R-squared & 0.07 & 0.07 & 0.12 & 0.12 & 0.09 & 0.04 & 0.05 & 0.09 & 0.39 & 0.387 & 0.414 \\
\hline Number of Observations & 3,113 & 3,068 & 3,068 & 3,068 & 2,240 & 2,240 & 2,240 & 2,240 & 2,240 & 1,125 & 1,115 \\
\hline
\end{tabular}

Percentage point change in cross-border US bank lending across countries and credit maturities

following a decrease in the US federal funds rate by 100 bps by lower (25\%) versus higher (75\%) liquid banks.

$$
5.12
$$

5.18

3.64

3.05

3.13

4.47

$3.72 \quad 2.79$

5.33

5.92

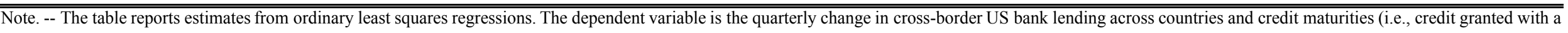

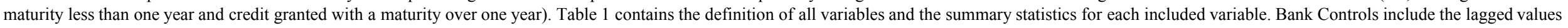

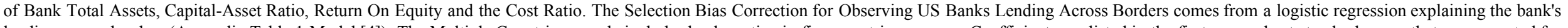
lending across borders (Appendix Table 1 Model [4]). The Multiple Countries sample includes banks active in five countries or more. Coefficients are listed in the first row, robust standard errors that are corrected for

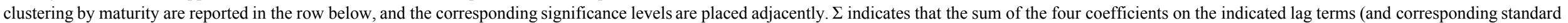

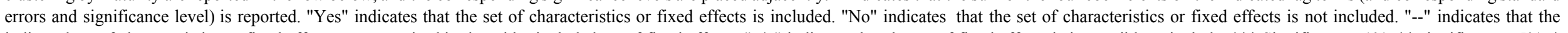

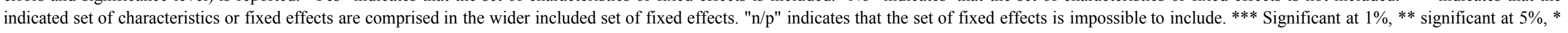
significant at $10 \%$ 
Table 3

Quarterly change in cross-border US bank lending across countries and credit maturities for banks with different capital ratios during the 2003:Q1-2007:Q4 period

\begin{tabular}{|c|c|c|c|c|c|c|c|c|c|c|c|}
\hline $\begin{array}{r}\text { Model } \\
\text { Sample of Banks } \\
\text { Included Maturities }\end{array}$ & $\begin{array}{l}{[1]} \\
A l l \\
\text { All }\end{array}$ & $\begin{array}{l}2] \\
A l l \\
\text { All }\end{array}$ & $\begin{array}{l}3] \\
A l l \\
\text { All }\end{array}$ & $\begin{array}{l}4] \\
\text { All } \\
\text { All }\end{array}$ & $\begin{array}{c}{[5]} \\
\text { Multiple } \\
\text { Countries } \\
\text { All }\end{array}$ & $\begin{array}{c}6] \\
\text { Multiple } \\
\text { Countries } \\
\text { All }\end{array}$ & $\begin{array}{c}{[7]} \\
\text { Multiple } \\
\text { Countries } \\
\text { All }\end{array}$ & $\begin{array}{c}{[8]} \\
\text { Multiple } \\
\text { Countries } \\
\text { All }\end{array}$ & $\begin{array}{c}{[9]} \\
\text { Multiple } \\
\text { Countries } \\
\text { All }\end{array}$ & $\begin{array}{c}{[10]} \\
\text { Multiple } \\
\text { Countries } \\
\leq 1 \text { Year }\end{array}$ & $\begin{array}{c}{[11]} \\
\text { Multiple } \\
\text { Countries } \\
>1 \text { Year }\end{array}$ \\
\hline$\Sigma \Delta$ US Federal Funds Rate $\{$ t -1 to $t-4\}$ & $\begin{array}{c}-11.401 \\
{[4.268]^{* * *}}\end{array}$ & $\begin{array}{c}-11.255 \\
{[4.308]^{* * *}}\end{array}$ & $\begin{array}{c}-10.298 \\
{[4.556]^{* *}}\end{array}$ & & $\begin{array}{c}-19.641 \\
{[1.098]^{* * *}}\end{array}$ & $\begin{array}{c}-9.715 \\
{[0.316]^{* * *}}\end{array}$ & & & & & \\
\hline$\Sigma \Delta$ US Federal Funds Rate $\{\mathrm{t}-1$ to $\mathrm{t}-4\} *$ Bank Capital Ratio $\{\mathrm{t}-1$ to $\mathrm{t}-4\}$ & $\begin{array}{c}0.669 \\
{[0.400]^{*}}\end{array}$ & $\begin{array}{c}0.672 \\
{[0.410]^{*}}\end{array}$ & $\begin{array}{c}0.649 \\
{[0.444]}\end{array}$ & $\begin{array}{c}0.636 \\
{[0.436]}\end{array}$ & $\begin{array}{c}1.474 \\
{[0.059]^{* * *}}\end{array}$ & $\begin{array}{c}0.713 \\
{[0.362]^{* *}}\end{array}$ & $\begin{array}{c}0.758 \\
{[0.347]^{* *}}\end{array}$ & $\begin{array}{c}1.476 \\
{[0.119]^{* * *}}\end{array}$ & $\begin{array}{c}0.208 \\
{[0.541]}\end{array}$ & $\begin{array}{c}0.284 \\
{[0.107]^{* * *}}\end{array}$ & $\begin{array}{c}-0.379 \\
{[0.487]}\end{array}$ \\
\hline$\Sigma$ Bank Capital Ratio $\{$ t -1 to $t-4\}$ & $\begin{array}{l}-0.370 \\
{[0.325]}\end{array}$ & $\begin{array}{l}-0.381 \\
{[0.323]}\end{array}$ & $\begin{array}{c}-0.411 \\
{[0.346]}\end{array}$ & $\begin{array}{c}-0.364 \\
{[0.285]}\end{array}$ & $\begin{array}{c}0.268 \\
{[0.824]}\end{array}$ & $\begin{array}{c}-0.318 \\
{[0.165]^{*}}\end{array}$ & $\begin{array}{c}-0.306 \\
{[0.126]^{* *}}\end{array}$ & $\begin{array}{c}0.400 \\
{[0.916]}\end{array}$ & $\begin{array}{c}0.663 \\
{[1.295]}\end{array}$ & $\begin{array}{c}0.052 \\
{[0.0124]^{* * *}}\end{array}$ & $\begin{array}{c}-0.100 \\
{[0.272]}\end{array}$ \\
\hline Constant & $\begin{array}{c}2.904 \\
{[8.316]}\end{array}$ & $\begin{array}{l}11.881 \\
{[8.995]}\end{array}$ & $\begin{array}{c}9.498 \\
{[9.440]}\end{array}$ & $\begin{array}{c}16.973 \\
{[9.944]^{*}}\end{array}$ & $\begin{array}{c}0.900 \\
{[27.332]}\end{array}$ & $\begin{array}{c}2.387 \\
{[2.038]}\end{array}$ & $\begin{array}{c}9.501 \\
{[5.216]}\end{array}$ & $\begin{array}{c}3.485 \\
{[20.503]}\end{array}$ & $\begin{array}{c}-6.551 \\
{[40.358]}\end{array}$ & $\begin{array}{c}10.330 \\
{[3.424]^{* * *}}\end{array}$ & $\begin{array}{c}8.620 \\
{[6.773]}\end{array}$ \\
\hline Bank Controls & Yes & Yes & Yes & Yes & Yes & Yes & Yes & Yes & Yes & Yes & Yes \\
\hline Host Country - Bank Fixed Effects & Yes & Yes & -- & -- & Yes & No & No & Yes & No & No & No \\
\hline Credit Maturity Fixed Effects & No & No & -- & -- & Yes & -- & -- & Yes & -- & -- & -- \\
\hline Host Country - Credit Maturity Fixed Effects & No & No & -- & -- & No & Yes & Yes & No & -- & -- & -- \\
\hline Host Country - Bank - Credit Maturity Fixed Effects & No & No & Yes & Yes & No & No & No & No & No & No & No \\
\hline Time Fixed Effects & No & No & No & Yes & No & No & Yes & Yes & -- & -- & -- \\
\hline Time - Host Country Fixed Effects & No & No & No & No & No & No & No & No & -- & Yes & Yes \\
\hline Time - Host Country - Credit Maturity Fixed Effects & No & No & No & No & No & No & No & No & Yes & $\mathrm{n} / \mathrm{p}$ & $\mathrm{n} / \mathrm{p}$ \\
\hline Selection Bias Correction for Observing US Banks Lending Across Borders & No & Yes & Yes & Yes & Yes & Yes & Yes & Yes & Yes & Yes & Yes \\
\hline R-squared & 0.07 & 0.07 & 0.11 & 0.12 & 0.08 & 0.03 & 0.04 & 0.08 & 0.32 & 0.31 & 0.33 \\
\hline Number of Observations & 4,216 & 4,171 & 4,171 & 4,171 & 3,298 & 3,298 & 3,298 & 3,298 & 3,298 & 1,672 & 1,626 \\
\hline
\end{tabular}

Percentage point change in cross-border US bank lending across countries and credit maturities

following a decrease in the US federal funds rate by 100 bps by lower (25\%) versus higher (75\%) capitalized banks:

$$
\begin{array}{llll}
3.47 & 3.47 & 3.35 & 3.30
\end{array}
$$

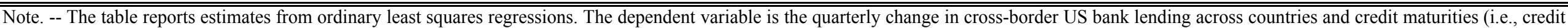

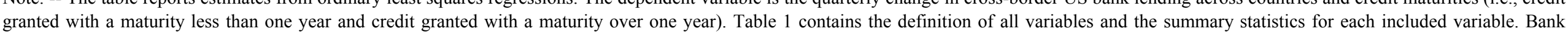

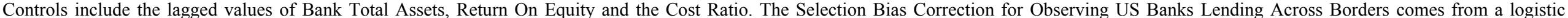

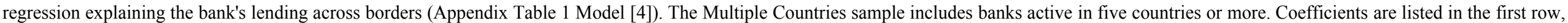

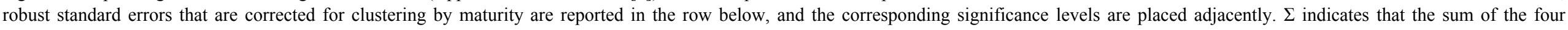

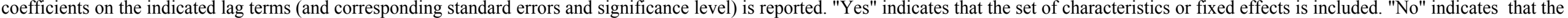

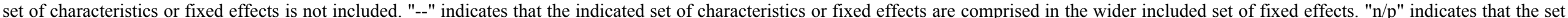
of fixed effects is impossible to include. *** Significant at $1 \%, * *$ significant at $5 \%$, * significant at $10 \%$. 
Table 4

Quarterly change in cross-border US bank lending across countries and sectors for banks with different liquidity or capital ratios during the 2003:Q1-2007:Q4 period

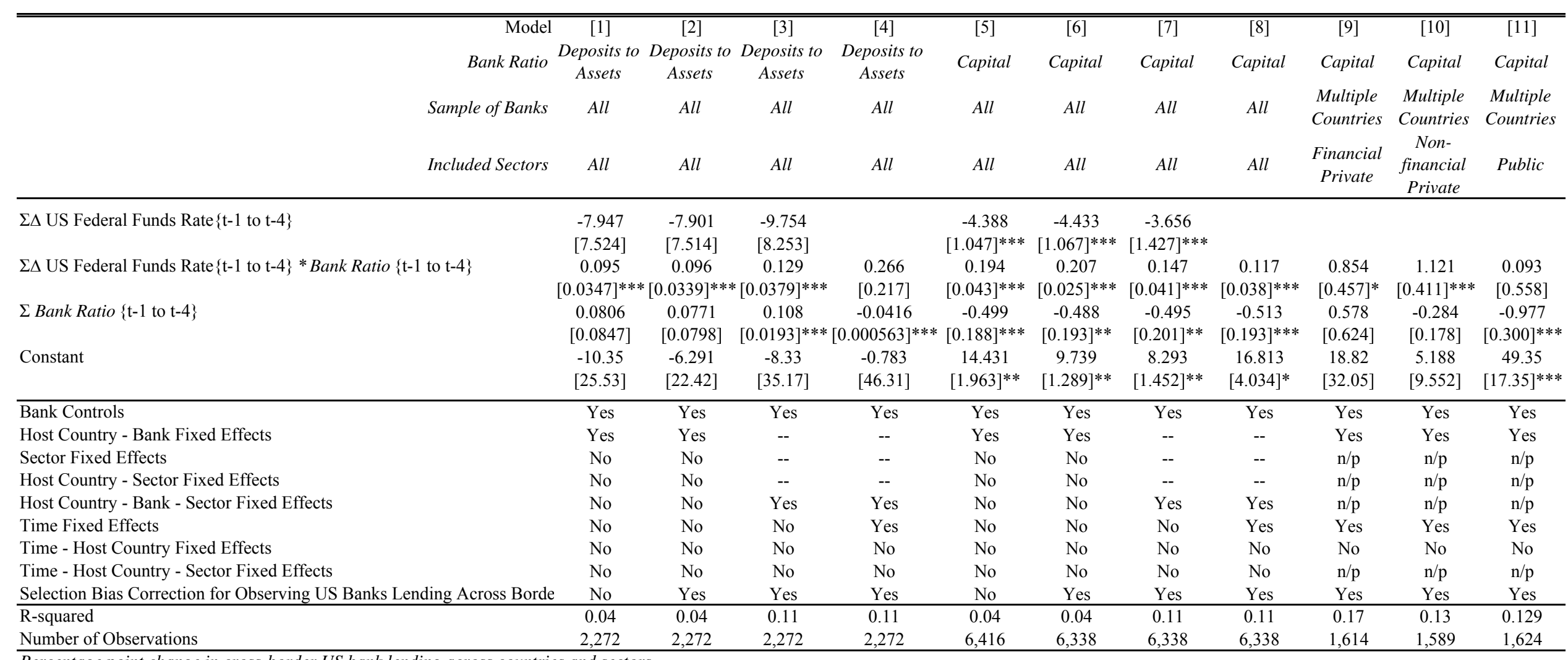

Percentage point change in cross-border US bank lending across countries and sectors

following a decrease in the US federal funds rate by 100 bps by lower (25\%) versus higher (75\%) capitalized banks:

$\begin{array}{llll}2.34 & 2.37 & 3.08 & 6.01\end{array}$

1.01

1.07

0.78

0.63

6.01

0.6

Note. -- The table reports estimates from ordinary least squares regressions. The dependent variable is the quarterly change in cross-border US bank lending across countries and sectors (i.e., the non-financial private

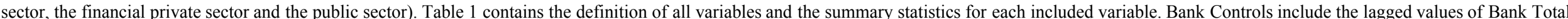

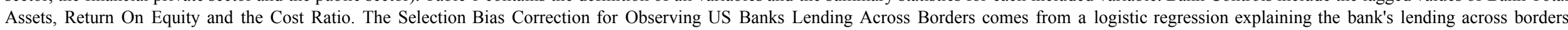

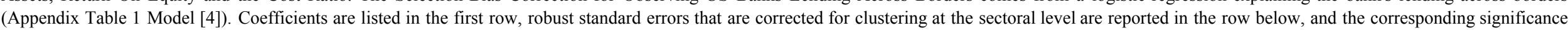

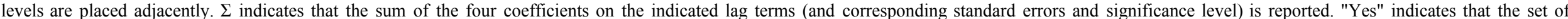

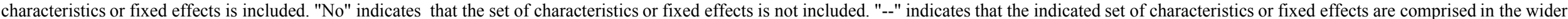
included set of fixed effects. ** Significant at $1 \%$, ** significant at $5 \%, *$ significant at $10 \%$. 
Table 5

Quarterly change in cross-border US bank lending across countries, credit maturities and sectors for banks with different liquidity or capital ratios during the 2008:Q1-2013:Q1 period

\begin{tabular}{|c|c|c|c|c|c|c|c|c|}
\hline $\begin{array}{r}\text { Model } \\
\text { Bank Ratio }\end{array}$ & $\begin{array}{c}{[1]} \\
\text { Deposits to } \\
\text { Assets } \\
\end{array}$ & $\begin{array}{c}{[2]} \\
\text { Capital }\end{array}$ & $\begin{array}{c}{[3]} \\
\text { Deposits to } \\
\text { Assets } \\
\end{array}$ & $\begin{array}{c}{[4]} \\
\text { Capital }\end{array}$ & $\begin{array}{c}{[5]} \\
\text { Deposits to } \\
\text { Assets } \\
\end{array}$ & $\begin{array}{c}6] \\
\text { Capital }\end{array}$ & $\begin{array}{c}{[7]} \\
\text { Deposits to } \\
\text { Assets } \\
\end{array}$ & $\begin{array}{c}{[8]} \\
\text { Capital }\end{array}$ \\
\hline$\Sigma \Delta$ US Krippner`s Shadow Short Rate $\{\mathrm{t}-1$ to $\mathrm{t}-4\} *$ Bank Ratio $\{\mathrm{t}-1$ to $\mathrm{t}-4\}$ & $\begin{array}{c}0.078 \\
{[0.165]}\end{array}$ & $\begin{array}{c}0.633 \\
{[0.354]^{*}}\end{array}$ & $\begin{array}{l}-0.208 \\
{[0.194]}\end{array}$ & $\begin{array}{c}0.546 \\
{[0.00252]^{* * *}}\end{array}$ & & & & \\
\hline$\Sigma \Delta$ US Federal Reserve's Sale of Securities $\{\mathrm{t}-1$ to $\mathrm{t}-4\} *$ Bank Ratio $\{\mathrm{t}-1$ to $\mathrm{t}-4\}$ & & & & & $\begin{array}{l}-0.056 \\
{[0.120]}\end{array}$ & $\begin{array}{c}-0.63 \\
{[0.390]}\end{array}$ & $\begin{array}{c}0.414 \\
{[0.180]^{* *}}\end{array}$ & $\begin{array}{c}0.167 \\
{[0.053]^{* * *}}\end{array}$ \\
\hline$\Sigma$ Bank Ratio $\{\mathrm{t}-1$ to $\mathrm{t}-4\}$ & $\begin{array}{c}-0.233 \\
{[0.329]}\end{array}$ & $\begin{array}{c}0.230 \\
{[0.187]}\end{array}$ & $\begin{array}{c}0.306 \\
{[0.144]^{* *}}\end{array}$ & $\begin{array}{c}0.228 \\
{[0.111]^{* *}}\end{array}$ & $\begin{array}{c}-8.7 \\
{[8.550]}\end{array}$ & $\begin{array}{c}-1.02 \\
{[1.350]}\end{array}$ & $\begin{array}{c}1.971 \\
{[8.370]}\end{array}$ & $\begin{array}{c}0.295 \\
{[1.782]}\end{array}$ \\
\hline Constant & $\begin{array}{c}180.500 \\
{[58.56]^{* * *}}\end{array}$ & $\begin{array}{c}5.616 \\
{[32.37]}\end{array}$ & $\begin{array}{c}-18.72 \\
{[10.44]^{*}}\end{array}$ & $\begin{array}{l}-0.283 \\
{[16.00]}\end{array}$ & $\begin{array}{c}189.6 \\
{[48.50]^{* * *}}\end{array}$ & $\begin{array}{c}16.21 \\
{[18.66]}\end{array}$ & $\begin{array}{l}-31.38 \\
{[22.61]}\end{array}$ & $\begin{array}{c}0.941 \\
{[24.52]}\end{array}$ \\
\hline Bank Controls & Yes & Yes & Yes & Yes & Yes & Yes & Yes & Yes \\
\hline Host Country - Bank - Credit Maturity Fixed Effects & Yes & Yes & No & No & Yes & Yes & No & No \\
\hline Host Country - Bank - Sector Fixed Effects & No & No & Yes & Yes & No & No & Yes & Yes \\
\hline Time Fixed Effects & Yes & Yes & Yes & Yes & Yes & Yes & Yes & Yes \\
\hline Selection Bias Correction for Observing US Banks Lending Across Borders & Yes & Yes & Yes & Yes & Yes & Yes & Yes & Yes \\
\hline R-squared & 0.178 & 0.208 & 0.175 & 0.179 & 0.181 & 0.203 & 0.178 & 0.177 \\
\hline Number of Observations & 1,845 & 2,997 & 3,722 & 4,570 & 1,845 & 3,016 & 3,757 & 4,599 \\
\hline
\end{tabular}

Note. -- The table reports estimates from ordinary least squares regressions. The dependent variable is the quarterly change in cross-border US bank lending across countries and credit maturities (i.e.,

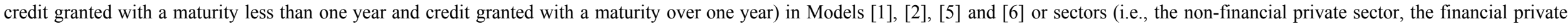

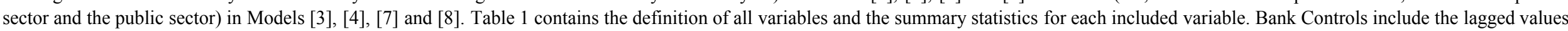

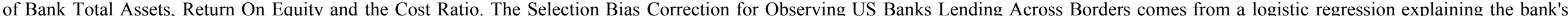

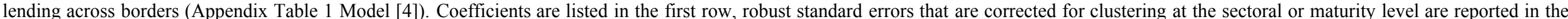

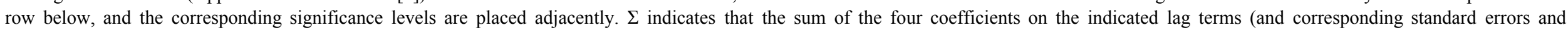

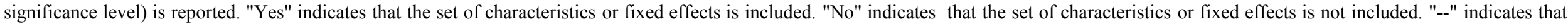
the indicated set of characteristics or fixed effects are comprised in the wider included set of fixed effects. *** Significant at $1 \%, * *$ significant at $5 \%$, $*$ significant at $10 \%$. 
Table 6

Quarterly change in cross-border US bank lending in lower income countries, credit maturities and sectors for banks with different liquidity or capital ratios

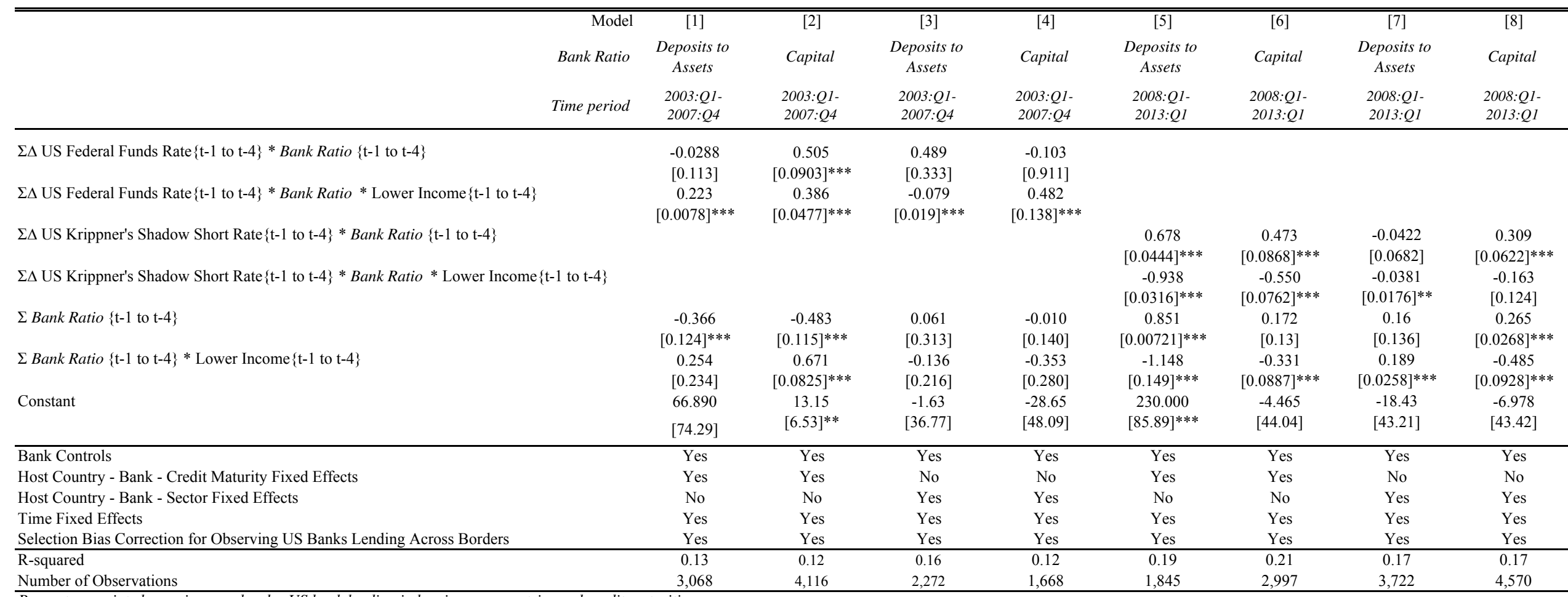

Percentage point change in cross-border US bank lending in low income countries and credit maturities

following a decrease in the US federal funds rate by 100 bps by lower (25\%) versus higher (75\%) capitalized banks:

Percentage point change in cross-border US bank lending in high income countries and credit maturities

4.63

$4.28 \quad 1.89$

2.29

$-1.29$

$-0.28$

$-0.39$

following a decrease in the US federal funds rate by 100 bps by lower (25\%) versus higher (75\%) capitalized banks:

\begin{tabular}{c}
0.02 \\
\hline
\end{tabular}

2.82

2.26

0.13

3.23

2.44

$-0.2$

cross-border US bank lending across countries and credit maturities (i.e, credit granted with a maturity less

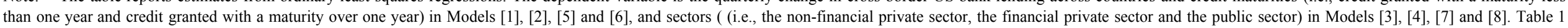

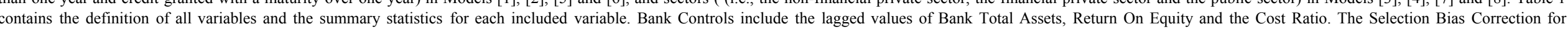

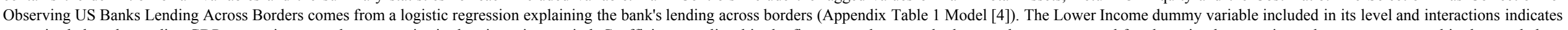

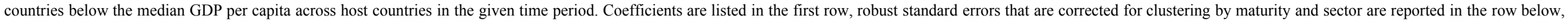

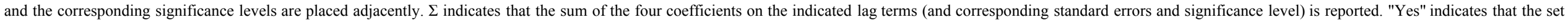

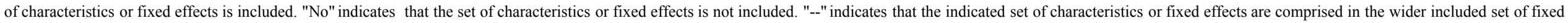
effects. "n/p" indicates that the set of fixed effects is impossible to include. ${ }^{* * *}$ Significant at $1 \%,{ }^{* *}$ significant at $5 \%, *$ significant at $10 \%$. 
Table 7

Quarterly change in US bank affiliate lending in other countries for banks with different capital ratios during the 2003:Q1-2007:Q4 period

\begin{tabular}{|c|c|c|c|c|c|c|c|c|}
\hline $\begin{array}{l}\text { Model } \\
\text { Sample of Host Countries }\end{array}$ & $\begin{array}{l}11] \\
\text { All }\end{array}$ & $\begin{array}{l}2] \\
\text { All }\end{array}$ & $\begin{array}{l}3] \\
\text { All }\end{array}$ & $\begin{array}{l}4] \\
\text { All }\end{array}$ & $\begin{array}{c}{[5]} \\
\text { Multiple } \\
\text { Lowly- } \\
\text { Dollarized } \\
\end{array}$ & $\begin{array}{c}{[6]} \\
\text { Multiple } \\
\text { Lowly- } \\
\text { Dollarized } \\
\end{array}$ & $\begin{array}{c}7] \\
\text { Multiple } \\
\text { Lowly- } \\
\text { Dollarized } \\
\end{array}$ & $\begin{array}{c}{[8]} \\
\text { Multiple } \\
\text { Lowly- } \\
\text { Dollarized } \\
\end{array}$ \\
\hline$\Sigma \Delta$ Host Country Short-Term Interest Rate $\{t-1$ to $t-4\}$ & $\begin{array}{l}-4.007 \\
{[2.34]^{*}}\end{array}$ & $\begin{array}{c}-4.902 \\
{[3.373]}\end{array}$ & & & $\begin{array}{l}-16.210 \\
{[9.288]^{*}}\end{array}$ & $\begin{array}{l}-15.400 \\
{[10.92]}\end{array}$ & & \\
\hline$\Sigma \Delta$ Host Country Short-Term Interest Rate $\{\mathrm{t}-1$ to $\mathrm{t}-4\} *$ Bank Capital Ratio $\{\mathrm{t}-1$ to $\mathrm{t}-4\}$ & $\begin{array}{c}0.754 \\
{[0.346]^{* *}}\end{array}$ & $\begin{array}{c}0.664 \\
{[0.327]^{* *}}\end{array}$ & $\begin{array}{c}0.369 \\
{[0.365]}\end{array}$ & $\begin{array}{c}0.648 \\
{[0.332]^{*}}\end{array}$ & $\begin{array}{c}2.473 \\
{[1.34]^{*}}\end{array}$ & $\begin{array}{c}2.784 \\
{[1.515]^{*}}\end{array}$ & $\begin{array}{c}1.803 \\
{[1.538]}\end{array}$ & $\begin{array}{c}2.112 \\
{[1.608]}\end{array}$ \\
\hline$\Sigma \Delta$ US Federal Funds Rate $\{\mathrm{t}-1$ to $\mathrm{t}-4\}$ & $\begin{array}{c}0.386 \\
{[5.377]}\end{array}$ & & & & $\begin{array}{c}6.739 \\
{[8.833]}\end{array}$ & & & \\
\hline$\Sigma \Delta$ US Federal Funds Rate $\{$ t- 1 to $t-4\} *$ Bank Capital Ratio $\{t-1$ to $t-4\}$ & $\begin{array}{c}-0.086 \\
{[0.278]}\end{array}$ & $\begin{array}{c}-0.117 \\
{[0.299]}\end{array}$ & $\begin{array}{c}-0.147 \\
{[0.503]}\end{array}$ & & $\begin{array}{c}0.021 \\
{[0.602]}\end{array}$ & $\begin{array}{c}0.221 \\
{[0.649]}\end{array}$ & $\begin{array}{c}-0.451 \\
{[0.715]}\end{array}$ & \\
\hline$\Sigma$ Bank Capital Ratio $\{$ t -1 to $t-4\}$ & $\begin{array}{l}-0.079 \\
{[0.31]}\end{array}$ & $\begin{array}{l}-0.097 \\
{[0.30]}\end{array}$ & $\begin{array}{l}-0.127 \\
0.294]\end{array}$ & $\begin{array}{c}-0.196 \\
{[0.275]}\end{array}$ & $\begin{array}{c}-0.285 \\
{[0.912]}\end{array}$ & $\begin{array}{c}-0.125 \\
{[0.809]}\end{array}$ & $\begin{array}{c}-0.228 \\
{[0.489]}\end{array}$ & $\begin{array}{c}-0.437 \\
{[0.427]}\end{array}$ \\
\hline Constant & $\begin{array}{l}21.320 \\
{[16.36]}\end{array}$ & $\begin{array}{c}18.120 \\
{[14.76]}\end{array}$ & $\begin{array}{c}14.86 \\
{[7.735]^{*}}\end{array}$ & $\begin{array}{c}12.520 \\
{[11.49]}\end{array}$ & $\begin{array}{l}35.940 \\
{[68.65]}\end{array}$ & $\begin{array}{c}16.010 \\
{[71.92]}\end{array}$ & $\begin{array}{c}12.340 \\
{[24.12]}\end{array}$ & $\begin{array}{l}-17.130 \\
{[105.8]}\end{array}$ \\
\hline Bank Controls & Yes & Yes & Yes & Yes & Yes & Yes & Yes & Yes \\
\hline Host Country Macro Controls & Yes & Yes & -- & -- & Yes & Yes & -- & -- \\
\hline Host Country - Bank Fixed Effects & Yes & Yes & No & No & Yes & Yes & No & No \\
\hline Time Fixed Effects & No & Yes & -- & -- & No & Yes & -- & -- \\
\hline Time - Host Country Fixed Effects & No & No & Yes & Yes & No & No & Yes & Yes \\
\hline Bank Fixed Effects & No & -- & Yes & Yes & No & -- & Yes & Yes \\
\hline Selection Correction for Observing US Banks Affiliate Presence in Host Country & Yes & Yes & Yes & Yes & Yes & Yes & Yes & Yes \\
\hline R-squared & 0.09 & 0.101 & 0.242 & 0.239 & 0.101 & 0.116 & 0.314 & 0.300 \\
\hline Number of Observations & 1,588 & 1,588 & 1589 & 1,588 & 509 & 509 & 509 & 509 \\
\hline
\end{tabular}

of Observations

1,588

1,588

following a decrease in the US federal funds rate by 100 bps by lower (25\%) versus higher (75\%) capitalized banks:

following a decrease in the host country short-term interest rate by 100 bps by lower (25\%) versus higher (75\%) capitalized banks:

$3.88 \quad 3.44 \quad 1.86$

$86 \quad 3.25 \quad 12.41$

13.95

$-2.84$

Note. -- The table reports estimates from ordinary least squares regressions. The dependent variable is the quarterly change in US bank affiliate lending in the host country. Table 1 contain the definition of all variables and the summary statistics for each included variable. Bank Controls include the lagged values of Bank Total Assets, Return On Equity and the Cost Ratio; the Host Country Macro Controls include the lagged quarterly changes in the host country's short term interest rate, the exchange rate and the host country's GDP. The Selection Bias Correction for Observing US Banks Affiliate Presence in Host Country comes from a logistic regression explaining the bank's presence in the host country (Appendix Table 2 Model 4). The Multiple Countries sample includes banks active in five countries or more. The Lowly-Dollarized Countries sample includes host countries for which the share of non-local currency to total US bank lending is below the 40 percentile across all countries that US banks lend to. Coefficients are listed in the first row, robust standard errors that are corrected for clustering at the sectoral level are reported in the row below, and the corresponding significance levels are placed adjacently. $\Sigma$ indicates that the sum of the four coefficients on the indicated lag terms (and corresponding standard errors and significance level) is reported. "Yes" indicates that the set of characteristics or fixed effects is included. "No" indicates that the set of characteristics or fixed effects is not included. "--" indicates that the indicated set of characteristics or fixed effects are comprised in the wider included set of fixed effects. *** Significant at $1 \%$, ** significant at $5 \%$, * significant at $10 \%$. 


\section{Appendix: Logistic estimation of global activity status and foreign market presence}

\section{A.1. Empirical Methodology}

Equation (A.1) describes the logistic formulation ${ }^{28}$ of the bank's globally active status.

(A.1) $G_{j, t}=\Lambda\left[\xi+\tau G_{t-1}+\sum_{k=1}^{4} o_{k} M P_{t-k}^{u s}+\sum_{k=1}^{4} \pi_{k} M P_{t-k}^{u s} \times C_{j, t-k}\right.$

$$
\left.+\sum_{k=1}^{4} \chi_{k} C_{j, t-k}+\varsigma\left(\begin{array}{c}
\text { Bank } \\
\text { Controls }
\end{array}\right)_{j, t-1}+\sigma\left(\begin{array}{c}
\text { Macro } \\
\text { Controls }
\end{array}\right)_{t-1}+v_{j, t}\right]
$$

In this expression, the indicator variable $G_{j, t}$ takes on a value of 1 if bank $j$ is globally active at time $t$, and $\Lambda[\bullet]$ denotes the cumulative density function of the logistic distribution. The explanatory variables are as defined in the text. Bank Controls includes total assets, return on equity and the cost to asset ratio and bank fixed effects. Macro Controls include U.S. GDP growth and U.S. CPI inflation. Various combinations of bank, bank home state and time fixed effects are also included, depending on the specification. If the extra liquidity provided by expansionary U.S. monetary policy increases the probability that a U.S. bank would extend claims beyond the domestic market, i.e. if the bank lending channel operates on the extensive margin as well, we expect to find $\sum_{k=1}^{4} o_{k}<0$ and $\sum_{k=1}^{4} \pi_{k}>0$. A potential explanation for the existence of such an external bank lending channel is that the liquidity improvement that banks experience after expansionary monetary policy might lead them to search for new investment opportunities. Establishing a department for foreign operations would enable the bank to tap into global investment outlets - via the acquisition of either cross-border or local claims. We calculate a Selection Correction statistic from the estimation of Equation (A.1) and use this variable as a regressor in Equation (1). We do so in order to control for the selection bias resulting from the fact that we only observe cross-

\footnotetext{
${ }^{28}$ In the presence of a large number of fixed effects, the use of a logistic formulation is much more suitable as compared to a probit specification.
} 
border flows from a select group of banks who have chosen to open global operations. The results of the Equation (A.1) estimations are discussed in the main text. ${ }^{29}$

Next, we present our specification for the logistic estimation of bank $j$ 's decision to maintain a local presence in host country $i$ at time $t$. Let $P_{j, t}^{i}$ denote an indicator variable that takes on a value of 1 if bank $j$ has an affiliate presence in host country $i$ at time $t$, and 0 otherwise.

(A.2) $P_{j, t}^{i}=\Lambda\left[6+\vartheta P_{j, t-1}^{i}+\sum_{k=1}^{4} \Upsilon_{k} M P_{t-k}^{u s}+\sum_{k=1}^{4} \phi_{k} M P_{t-k}^{u s} \times C_{j, t-k}\right.$

$$
\left.+\sum_{k=1}^{4} \varpi_{k} C_{j, t-k}+\kappa\left(\begin{array}{c}
\text { Bank } \\
\text { Controls }
\end{array}\right)_{j, t-1}+\mathrm{F}\left(\begin{array}{c}
\text { Macro } \\
\text { Controls }
\end{array}\right)_{t-1}^{i}+\epsilon_{j, t}^{i}\right]
$$

Where $\Lambda$ is the logistic CDF, and $P_{j, t-1}^{i}$ is the one-quarter lagged value of the foreign market presence indicator variable. The explanatory variables are as defined in the main text. The Bank Controls included in Equation (A.2) are total assets, return on equity and the cost-to-asset ratio. The Macro Controls, included in some specifications, contain the quarterly changes in the host country's short-term interest rate, GDP and the host-U.S. exchange rate. All specifications contain host country fixed effects, and we also add bank fixed effects as we saturate our model. If the extra liquidity resulting from expansionary U.S. monetary policy contributes to the probability that a U.S. bank would establish local presence in a foreign country that it already sends cross-border investments to, then we expect to find $\sum_{k=1}^{4} \Upsilon_{k}<0$ and $\sum_{k=1}^{4} \phi_{k}>0$. These findings would be indicative of the existence of an extensive margin bank lending channel. A potential explanation for why U.S. banks' choice to establish local presence abroad might be affected by the stance of monetary policy in the U.S. is that doing so enables the bank to extend local flows in the host market. Therefore, establishing an affiliate opens up a new channel for bilateral foreign investment in that market. Such new channels might be increasingly attractive to U.S.

\footnotetext{
${ }^{29}$ The exclusion restrictions (i.e., variables which are included in the logit estimation but not in the cross-border flows regressions) are the lagged values of the dependent variable, the US macro controls (GDP Growth and CPI Inflation) and the bank type and home state fixed effects.
} 
banks as liquidity conditions at home improve in response to expansionary monetary policy. We calculate a Selection Correction statistic from the estimation of Equation (A.2) and use this variable as a regressor in Equation (2). We do so in order to control for the selection bias resulting from the fact that we only observe local flows for a select group of foreign countries whose lucrative investment prospects have led U.S. banks to establish local presence there. Results of the estimation of Equation (A.2) are discussed in the main text. ${ }^{30}$

\section{A.2. Data}

The dataset used in the estimation of banks' globally active status in Equation (A.1) incorporates all U.S. financial institutions that report on the Call Reports. Therefore, the data covers balance sheet and financial data for over 18 thousand U.S. financial institutions, including commercial banks, bank holding companies, and edge and agreement corporations. In order to identify those banks with significant foreign exposures, the dependent variable is an indicator that takes on a value of 1 if the bank reports its foreign exposure on the FFIEC 009a form, and 0 otherwise. List of Host Countries: Afghanistan; Argentina; Australia; Austria; Bahamas, Barbados, Belgium; Bermuda; Bolivia; Brazil; Canada; Chile; China; Colombia; Costa Rica; Cuba; Cyprus; Czech Republic; Denmark; Dominican Republic; Ecuador; El Salvador; Finland; France; Germany; Ghana; Greece; Guatemala; Haiti; Honduras; Hong Kong; Hungary; Iceland; India; Indonesia; Ireland; Israel; Italy; Jamaica; Japan; Jordan; Kazakhstan; South Korea; Kuwait; Liberia; Luxembourg; Mauritius; Mexico; Netherlands; New Zealand; Nicaragua; Norway; Panama; Paraguay; Peru; Philippines; Poland; Portugal; Romania; Russia; Saudi Arabia; Singapore; South Africa; Spain; Sweden; Switzerland; Taiwan; Thailand; Trinidad and Tobago; Turkey; United Arab Emirates; United Kingdom; Uruguay; Venezuela.

\footnotetext{
${ }^{30}$ The exclusion restrictions (i.e., variables which are included in the logit estimation but not in the affiliate flows regressions) are the lagged values of the dependent variable, and (depending on the specification in Table 7) the level of US Fed Funds rate changes or host country macro controls.
} 
Appendix Table 1

US banks lending across borders during the 2003:Q1-2007:Q4 period

\begin{tabular}{|c|c|c|c|c|}
\hline Model & [1] & [2] & [3] & [4] \\
\hline \multirow[t]{2}{*}{ US Banks Lending across Borders $\{\mathrm{t}-1\}$} & 0.695 & 2.029 & 2.356 & 1.982 \\
\hline & {$[0.192]^{* * *}$} & {$[0.209]^{* * *}$} & {$[0.252]^{* * *}$} & {$[0.197]^{* * *}$} \\
\hline \multirow[t]{2}{*}{$\Sigma \Delta$ US Federal Funds Rate $\{$ t -1 to $t-4\}$} & -0.301 & -1.016 & -1.207 & \\
\hline & {$[0.054]^{* * *}$} & {$[0.124]^{* * *}$} & {$[0.149]^{* * *}$} & \\
\hline \multirow[t]{2}{*}{$\Sigma \Delta$ US Federal Funds Rate $\{$ t -1 to $t-4\} *$ Bank Capital Ratio $\{$ t -1 to t- 4$\}$} & -0.001 & -0.001 & -0.001 & -0.009 \\
\hline & {$[0.003]$} & {$[0.006]$} & {$[0.007]$} & {$[0.015]$} \\
\hline \multirow[t]{2}{*}{$\Sigma$ Bank Capital Ratio $\{$ t -1 to $t-4\}$} & -0.002 & -0.005 & -0.007 & -0.009 \\
\hline & {$[0.001]^{*}$} & {$[0.003]^{*}$} & {$[0.003]^{* *}$} & {$[0.003]$} \\
\hline \multirow[t]{2}{*}{ Bank Total Assets $\{t-1\}$} & 0.029 & 0.101 & 0.115 & 0.112 \\
\hline & {$[0.006]^{* * *}$} & {$[0.017]^{* * *}$} & {$[0.017]^{* * *}$} & {$[0.014]^{* * *}$} \\
\hline \multirow[t]{2}{*}{ Bank Return on Equity $\{t-1\}$} & -0.003 & -0.005 & -0.006 & -0.01 \\
\hline & {$[0.001]^{* *}$} & {$[0.003]$} & {$[0.004]$} & {$[0.006]^{*}$} \\
\hline \multirow[t]{2}{*}{ Bank Cost Ratio $\{$ t -1$\}$} & 0.001 & 0.006 & 0.007 & -0.001 \\
\hline & {$[0.002]$} & {$[0.004]^{*}$} & {$[0.007]$} & {$[0.009]$} \\
\hline \multirow[t]{2}{*}{ US GDP Growth $\{\mathrm{t}-1\}$} & 0.126 & 0.418 & 0.489 & \\
\hline & {$[0.075]^{*}$} & {$[0.190]^{* *}$} & {$[0.222]^{* *}$} & \\
\hline \multirow[t]{2}{*}{ US CPI Inflation $\{t-1\}$} & 0.108 & 0.351 & 0.412 & \\
\hline & {$[0.027]^{* * *}$} & {$[0.075]^{* * *}$} & {$[0.088]^{* * *}$} & \\
\hline Bank Type Fixed Effects & Yes & No & Yes & Yes \\
\hline Home State Fixed Effects & No & Yes & Yes & Yes \\
\hline Time Fixed Effects & No & No & No & Yes \\
\hline Number of Observations & 126,725 & 37,781 & 32,098 & 30,241 \\
\hline
\end{tabular}

Note. -- The table reports estimates of marginal effects (in percent) from logit regressions. The dependent variable is a dummy that equals 1 if a US bank lends across border in $t$ (year:quarter) and is 0 otherwise. Table 1 contains the definition of all variables and the summary statistics for each included variable. Marginal effects are listed in the first row, robust standard errors are reported in the row below, and the corresponding significance levels are placed adjacently. $\Sigma$ indicates that the sum of the four coefficients on the indicated lag terms (and corresponding standard errors and significance level) is reported. "Yes" indicates that the set of characteristics or fixed effects is included. "No" indicates that the set of characteristics or fixed effects is not included. *** Significant at $1 \%$, ** significant at $5 \%, *$ significant at $10 \%$. 
Appendix Table 2

US banks affiliate presence in host countries during the 2003:Q1-2007:Q4 period

\begin{tabular}{|c|c|c|c|c|}
\hline Model & {$[1]$} & {$[2]$} & [3] & [4] \\
\hline US Banks Affiliate Presence in Host Country $\{t-1\}$ & $\begin{array}{c}19.282 \\
{[0.673]^{* * *}}\end{array}$ & $\begin{array}{c}19.426 \\
{[0.696]^{* * *}}\end{array}$ & $\begin{array}{c}32.785 \\
{[1.443]^{* * *}}\end{array}$ & $\begin{array}{c}32.393 \\
{[1.384]^{* * *}}\end{array}$ \\
\hline$\Sigma \Delta$ US Federal Funds Rate $\{\mathrm{t}-1$ to $\mathrm{t}-4\}$ & $\begin{array}{c}-0.61 \\
{[2.030]}\end{array}$ & $\begin{array}{c}-4.994 \\
{[2.085]^{*}}\end{array}$ & $\begin{array}{c}-11.714 \\
{[9.256]}\end{array}$ & $\begin{array}{c}-22.686 \\
{[10.063]^{* *}}\end{array}$ \\
\hline$\Sigma \Delta$ US Federal Funds Rate $\{$ t -1 to $t-4\} *$ Bank Capital Ratio $\{$ t- 1 to $t-4\}$ & $\begin{array}{c}0.141 \\
{[0.121]}\end{array}$ & $\begin{array}{c}0.133 \\
{[0.121]}\end{array}$ & $\begin{array}{c}2.43 \\
{[0.951]^{* * *}}\end{array}$ & $\begin{array}{c}2.384 \\
{[0.994]^{* *}}\end{array}$ \\
\hline$\Sigma$ Bank Capital Ratio $\{t-1$ to $t-4\}$ & $\begin{array}{c}-0.069 \\
{[0.102]}\end{array}$ & $\begin{array}{c}-0.075 \\
{[0.098]}\end{array}$ & $\begin{array}{c}-1.983 \\
{[0.461]^{* * *}}\end{array}$ & $\begin{array}{c}-1.856 \\
{[0.520]^{* * *}}\end{array}$ \\
\hline Bank Total Assets $\{t-1\}$ & $\begin{array}{c}0.989 \\
{[0.243]^{* * *}}\end{array}$ & $\begin{array}{c}0.999 \\
{[0.248]^{* * *}}\end{array}$ & $\begin{array}{c}0.52 \\
{[0.675]}\end{array}$ & $\begin{array}{c}0.158 \\
{[0.705]}\end{array}$ \\
\hline Bank Return on Equity $\{\mathrm{t}-1\}$ & $\begin{array}{c}-0.036 \\
{[0.045]}\end{array}$ & $\begin{array}{c}-0.038 \\
{[0.045]}\end{array}$ & $\begin{array}{c}-0.143 \\
{[0.125]}\end{array}$ & $\begin{array}{c}-0.117 \\
{[0.135]}\end{array}$ \\
\hline Bank Cost Ratio $\{\mathrm{t}-1\}$ & $\begin{array}{c}0.077 \\
{[0.057]}\end{array}$ & $\begin{array}{c}0.077 \\
{[0.060]}\end{array}$ & $\begin{array}{c}-0.238 \\
{[0.117]^{* *}}\end{array}$ & $\begin{array}{c}-0.228 \\
{[0.119]^{*}}\end{array}$ \\
\hline Bank Fixed Effects & No & No & Yes & Yes \\
\hline Host Country Macro Controls & No & Yes & No & Yes \\
\hline Host Country Fixed Effects & Yes & Yes & Yes & Yes \\
\hline Number of Observations & 1,711 & 1,711 & 750 & 750 \\
\hline
\end{tabular}

Note. -- The table reports estimates of marginal effects (in percent) from logit regressions. The dependent variable is a dummy that equals 1 if a US bank has an affiliate in the host country at time $t$ (year:quarter) and is 0 otherwise. The Host Country Macro Controls include the lagged quarterly changes in the host country's short-term interest rate, the host country's GDP and the exchange rate. Table 1 contains the definition of all variables and the summary statistics for each included variable. Marginal effects are listed in the first row, robust standard errors are reported in the row below, and the corresponding significance levels are placed adjacently. $\Sigma$ indicates that the sum of the four coefficients on the indicated lag terms (and corresponding standard errors and significance level) is reported. "Yes" indicates that the set of characteristics or fixed effects is included. "No" indicates that the set of characteristics or fixed effects is not included. *** Significant at $1 \%$, ** significant at $5 \%, *$ significant at $10 \%$. 